\title{
Veri Analizi Konusunda Kullanılan Portfolyo Değerlendirmesinin 7. Sınıf Öğrencilerinin İstatistik Başarısına Etkisi
}

\section{The Effect of Portfolio Assessment Used in Data Analysis Unit on 7th Grade Students' Statistics Achievement}

\author{
Bengi BİRGİLI*, Utkun AYDIN**
}

\begin{abstract}
Öz: Bu çalışmanın amacı portfolyo değerlendirmesinin istatistik başarısı üzerindeki etkisini incelemektir. Çalışma, İstanbul ili Fatih ilçesinde bulunan bir ortaokulda öğrenim görmekte olan 7. sınıf öğrencilerinin katılımıyla iki ayrı sınıfta yürütülmüş̧ür. Araştırmada yarı deneysel desen kullanılmış ve deney grubunda 32, kontrol grubunda 32 olmak üzere toplam 64 öğrenci ile çalışılmıştır. Deney ve kontrol grubunda yer alan öğrencilerin istatistik başarısı araştırmacılar tarafından veri analizi ünitesi içeriğinde geliştirilen İstatistik Başarı Testi (IBT) ile ölçülmüş, öntest ve cinsiyet değişkenleri kontrol altında tutularak sontest puanları arasındaki değişim incelenmiştir. Uygulama 6 hafta boyunca yürütülmüştür. Uygulama boyunca veri analizi ünitesi kontrol grubunda mevcut öğretim programına göre, deney grubunda ise mevcut öğretim programına ek olarak portfolyo değerlendirmesi kullanılarak işlenmiştir. Elde edilen verilerin analizinde İlişkili Örneklemler t-testi, İlişkisiz Örneklemler t-testi, ve Çift-Faktörlü Kovaryans Analizi kullanılmıştır. Araştırmanın sonuçları, portfolyo değerlendirmesi kullanılan öğretimin istatistik başarısını deney grubu lehine anlamlı düzeyde etkilediğini göstermiştir.
\end{abstract}

Anahtar Kelimeler: Portfolyo, istatistik eğitimi, veri analizi, ortaokul matematiği, deneysel çalışma

\begin{abstract}
The aim of this study is to investigate the effect of portfolio assessment on statistics achievement. The research was carried out with 7th grade students in two different classes, who are attending to a public school in Fatih, İstanbul-Turkey. A total of 64 students $(n=32$ in experimental and $n=32$ in control) participated in this quasi-experimental study. Students' statistics achievement was measured through the researcher-developed Statistics Achievement Test (SAT), which covered data analysis unit. The quantitative data was obtained from the results of pre-test and post-test measurement within the 6-week treatment. The difference between the post-test scores was investigated by controlling pre-test scores and gender. In the experimental group the data analysis unit was carried out in guidance of the current middle school mathematics program plus the portfolio assessment, whereas in the control group only the activities and examples present in the current middle school mathematics program was used. Data were analyzed by performing Paired Samples t-Test, Independent Samples t-Test, and Two-Factor ANCOVA. Results revealed that portfolio assessment, as compared to traditional techniques, had a significant effect on students' statistics achievement.
\end{abstract}

Keywords: Portfolio, statistics education, data analysis, middle school mathematics, experimental study

\section{Giriş}

Geçmişten günümüze matematik eğitimi alanında yaşanan gelişmeler öğrencilerin öğrenme süreçlerinde ve bu süreçlerin ölçme-değerlendirilmesinde birçok yenilik sağlamıştır. Bu yenilikçi yaklaşımlar öğrenci başarısının 'ne kadar'dan (nicel) ziyade 'ne kadar iyi'ye (nitel) bağlı olduğunun altını çizmektedir (Hargreaves, 1997). Dolayısıyla değerlendirme araçları öğrencilerin 'ne bildikleri' yerine 'bildikleri ile ne yapabilecekleri'ni ölçmek üzere kullanılmalıdır (Struyyen, Dochy, Janssens, Schelfout ve Gielen, 2006). Bu görüşü benimseyen yapılandırıcı öğrenme yöntemlerinde, genellikle öğretim sürecinden ayrı, yalnızca ürüne (ör., yazılı sınav, sözlü yoklama, çoktan seçmeli test) ağırlık veren geleneksel yöntemlerin aksine ölçme ve

* Arş. Gör., MEF Üniversitesi, Eğitim Fakültesi, İstanbul-Türkiye, 0000-0002-2990-6717, e-posta: birgilib@mef.edu.tr

** Doç. Dr., American University of the Middle East, College of Engineering and Technology, Kuwait, 0000-00021380-5911, e-posta: Utkun.Aydin@aum.edu.kw 
değerlendirme öğrenme süreci boyunca, gerek öğrenmenin başında gerekse sonunda, öğretimin bir parçası olarak ele alınmaktadır (Toptaş, 2011). Amerikan Matematik Öğretmenleri Birliği'nin (National Council of Teachers of Mathematics) eğitim programları ve değerlendirme için yayınladığı standartlara göre, değerlendirme araçları yazılı, sözel, görsel temsilleri içermeli ve öğrenciyi öğrenmeye teşvik etmelidir (NCTM, 2000). İlköğretim seviyesinde bu değerlendirme yöntemini kullanmak öğrenci hakkında net bilgiler edinilmesine, zayıf yönlerinin keşfedilmesine ve öğretmenin kendi yöntemini planlamasına yardım etmektedir. Benzer şekilde Milli Eğitim Bakanlığı matematik programlarında da ölçme-değerlendirmenin öğrencinin güçlü ve zayıf yönlerini ortaya çıkaracak şekilde izlemeyi amaçladığı ve öğrenme sürecini destekleyecek nitelikte olması gerektiği vurgulanmaktadır (MEB, 2005, 2018, s. 43).

Tüm bunlar geleneksel olarak kullanılan kağıt-kalem testlerinin yanı sıra öğrenciyi de süreç içerisine katan geniş perspektifli ölçme-değerlendirme araçlarının (ör., sunum, özdeğerlendirme, deney, proje) kullanılmasını da beraberinde getirmiştir. Ölçme-değerlendirme perspektifinden yaklaşıldığında matematik dersinin değerlendirilmesinde kullanılan klasik/standardize testlerle öğrenci başarısının sadece bir kısmının ölçülebildiği, diğer matematiksel becerilerin (ör., problem çözme, problem kurma, yaratıcılık, hayal gücü, muhakeme yapma vb.) birçoğunun göz ardı edildiği tespit edilmiş̧ir (Ben-Hur, 2006; Gelbal ve Kelecioğlu, 2007; Kılıç, 2012; Kınay, 2015). Buna karşıllı, alternatif ölçme-değerlendirme araçlarından portfolyo öğrencilerin üst düzey bilişsel becerilerinin ortaya çıkmasını sağlayarak onların bilgiyi nasıl sentezlediklerini sergilemelerine olanak sağlamaktadır (Koca ve Lee, 2001). Öğretmenler ise daha esnek bir yaklaşımla öğrencilerin hem güçlü hem de zayıf yanlarını belirleyerek onların geliştirilmesi gereken yönlerine odaklanabilmektedir (Lombardi, 2008).

\section{Literatür}

\section{Portfolyo}

Portfolyo Latince "portare" ve "foglio" kelimelerinin birleşiminden oluşan sıraya konmuş kağıt kümeleri anlamına gelmektedir (Sharp, 2002). Genel anlamda bir veya daha fazla alanda öğrencinin kendi gelişimini ve başarısını takip etmesine yarayan, öğrencinin çalışmalarının toplamı şeklinde tanımlanmaktadır (Birgin ve Baki, 2007). Daha özel olarak, Türkçe’ye portföy (Bkz. Türk Dil Kurumu) terimi ile uyarlanmış, bir kişinin "kazanç sağlamak amacıyla oluşturduğu mali varlıklar bütünü" olarak ifade edilmiştir. Eğitim ve öğretim sürecinde portföy terimi portfolyo kavramı olarak yerleşmiş ve ürün dosyası olarak da nitelendirilmiştir. Portfolyo, öğrencilerin eğitim programlarında belirlenen öğrenme hedef ve davranışlarına ne düzeyde ulaşıldığına yönelik kanıtlar ortaya koymaya yarar (Lustig, 1996). Bu kanıtlardan bir kısmı da öğrencilerin öğrenme sürecinde ürettikleri özgün ürünlerdir. Bu kapsamda kanıtları gösterebilmek için öğrenci çalışmalarının belirli bir amaca yönelik olarak düzenli bir biçimde belli zaman içerisinde toplanarak eğitimci tarafından ölçme-değerlendirme sürecinde kullanılmaktadır (McMillan, 2007). Sonuçtan ziyade süreç odaklı bir ölçme-değerlendirme yaklaşımı çerçevesinde öğrencilerin hem güçlü hem de geliştirilmesi gereken yönlerini belirlemektedir (Koreneekij, 2008). Zamanla ilköğretim kademesinden yükseköğretime kadar yaygınlaşmış (Polat-Demir ve Kutlu, 2016), bir öğrencinin ilgi duyduğu bilim alanı ya da dersteki gelişiminin süreç içerisindeki takibinde tercih edilmiştir (Mamur, 2012; Popham, 2011). Dünyaca ünlü bilim insanları (ör., Charles Darwin) ve sanatçıları (ör., Leonardo Da Vinci, Vincent Van Gogh) tarafından da kullanılan portfolyo, anlaşılacağı üzere çalışmaları sunma, görsel ifadeleri yansıtma ve bir konudaki yeterlikleri gösterme amacını taşımaktadır. Ülkemizde de pek çok ünlü sanatçı (ör., Fikret Mualla, Abidin Dino, Bedri Rahmi Eyuboğlu) tasarımlarını sunmak üzere portfolyo çalışmaları yapmıştır (IKSV Tasarım, 2007). Bilimin her alt dalında olduğu gibi matematik eğitiminde de portfolyo kullanımı öğrenenlerin öğrenme sürecinde çalışmalarını sunmak ve yeterliklerini göstermek istemesi süreçte dönüt alarak ilerlemesine ve gelişmesine katk1 sağlamaktadır (Gelbal ve Kelecioğlu, 2007). Gerçekten de ölçme araçlarından elde edilen verilerle yapılan değerlendirmeler hem öğrenciler ve öğretmenler hem de geliştirilen öğretim programlarına dönüt olarak kullanılıp eğitim-öğretimin olumlu yönde gelişimine anlamlı katk1 sağlayabilirler (MEB, 2005, 2018). Buna rağmen portfolyo değerlendirmesinin bazı 
dezavantajları şöyle sıralanabilir (Aktay ve Gültekin, 2014): (1) bireysel çalışma ve üretime dayandığı için puanlama güvenirliği düşüktür; (2) hazırlanma esnasında detaylı inceleme gerektirir; ve (3) öğrenciyi yönlendirmek zaman alıcıdır. Bu sınırlılıklarına rağmen son yıllarda eğitim öğretim sürecinde gerek öğrenme gerekse bir değerlendirme yöntemi olarak tercih edilmektedir (Demirören, Koşan ve Palaoğlu, 2009). Öğretmenlerin matematik dersi kapsamında alternatif ölçme ve değerlendirme yöntemlerinin kullanımı ile algılarını araştıran birçok ulusal çalışma sonuçlarında öğretmenlerin portfolyo kullanımına ilişkin olumlu görüş belirttikleri ve sıklıkla kullanılan bir değerlendirme yöntemi olduğu rapor edilmiştir (Güneş ve Baki, 2011; Mutlu ve Özden, 2017; Orbeyi ve Güven, 2008; Toptaş, 2011). Bu bağlamda 1980'li y1llardan beri eğitimde ölçme-değerlendirme süreçlerinde kullanılmakta olan portfolyonun, öğrencilerin performansına (Henderson, Davis ve Day, 1995) ve akademik başarısına olumlu yönde etki ettiği birçok çalışma sonuçları ile kanıtlanmıştır (detayları ile görmek için bkz. Başol ve Erbay, 2017 meta analiz çalışması).

\section{Istatistik eğitimi ve portfolyo kullanımı}

İstatistik eğitimi matematik eğitimi alanından evrimleşerek istatistik öğretimi ve öğrenimine odaklanan disiplinlerarası bir alandır (Zieffler, Garfield ve Fry, 2018). Ülkemizde ilkokul (1-4. Sınıflar) ve ortaokul (5-8. Sınıflar) matematik dersi programına Veri İşleme öğrenme alanı adı altında katılarak Veri Toplama ve Değerlendirme ve Veri Analizi alt öğrenme alanlarına ayrılmıştır (MEB, 2018). Ortaöğretim (9-12. Sınıflar) matematik programında Veri, Sayma ve Olasılık öğrenme alanı adı altında katılarak Veri ve Veri Analizi alt öğrenme alanlarına ayrılmıştır (MEB, 2018). Diğer uluslararası dokümanlarda ise okul öncesi eğitimden başlayarak liseye kadar (K-12) Veri Analizi ve Olasılık içerik standardı olarak yerini almıştır (NCTM, 2000). Açıkça görülmektedir ki verinin toplanması, işlenmesi ve analiz edilip çıkarımların yapılmasının karar verilmesinde, karar kalitesinin artmasında, doğru stratejilerin belirlenip işlenmesinde önemli rol oynamaktadır (Koparan, 2013). Bu da istatistik eğitiminin önemini gözler önüne sermektedir (Temiz ve Tan, 2009). Çalışmamızda kaynak olarak kullanılan 5. sınıf ders kitabında öğrenme alanı Olasılık ve İstatistik olarak belirtilmiş olup alt öğrenme alanlarında, tablo ve grafikler, merkezi eğilim ve yayılma ölçüleri bulunmaktadır. Bu nedenle tüm konu ve kazanımlar bu çalışmanın kapsamında genel olarak "istatistik" başarısı adı altında tanımlanmıştır. Nitekim ortaokul seviyesindeki öğrencilerin istatistiksel düşünebilmelerinin dört önemli bileşeni: verinin tanımlanması, verinin organize edilmesi ve indirgenmesi, veri gösterimi, verinin analiz edilmesi ve yorumlanmasidır (Koparan, 2013; Koparan ve Güven, 2014a).

İstatistik eğitimi araştırmaları incelendiğinde çalışmaların istatistik başarısı ve istatistiğe karş1 tutum (Doğan, 2009), istatistiksel düşünme (Koparan ve Güven, 2014a), istatistiksel okuryazarlık (Karaman ve Şahin, 2013; Koparan ve Güven, 2014b), istatistiksel dil becerileri (Çakmak, Çetin ve Bektemir, 2016) ve istatistiksel düşünme modelleri (Chance, 2002; Koparan, 2013) konularına yoğunlaştığı görülmektedir. Bu çalışmaların birçoğu ortaokul seviyesinde (ör., Çakmak, Çetin ve Bektemir, 2016; Koparan ve Güven, 2014a; 2014b) ve çok az bir kısmı ise ilkokul (Jones, Langrall, Mooney ve Thornton, 2004, aktaran Biehler ve diğerleri, 2018), lise (Makar ve Rubin, 2018 p. 280) ve üniversite (Doğan, 2009; Onwuegbuzie ve Leech, 2003; Verhoeven, 2006; Makar ve Rubin, 2018, s. 284) seviyesindedir. Metodolojik açıdan incelendiğinde ise çalışmaların büyük bir kısmının nicel araştırmalar olduğu ve deneysel (ör., Doğan, 2009; Petocz, Reid, ve Gal, 2018 p.83); boylamsal (Gil ve Ben-Zvi, 2014; Koparan ve Güven, 2014a; Watson, Fitzallen, Fielding-Wells ve Madden, 2018); yapısal eşitlik modellemesi (ör., Çakmak, Çetin ve Bektemir, 2016; Petocz, Reid ve Gal, 2018 p.83) tekniklerinin kullanıldı̆̆ görülmektedir. İstatistik eğitimi alanında yapılan ulusal çalışmalar ise yok denecek kadar azdır (ör., Çakmak, Çetin ve Bektemir, 2016; Doğan, 2009).

Ulusal ve uluslararası araştırmalar ilköğretim, ortaöğretim hatta üniversite seviyesindeki birçok öğrencinin temel istatistiksel konularını öğrenmede ve anlamada güçlük çektiğini vurgulamaktadır (ör., Ben-Zvi, Gravemeijer ve Ainley, 2017; Doğan, 2009; Schindler ve Seidouvy, 2019). Araştırmacılar bu zorluklara neden olarak öğrencilerin matematik önbilgilerinin ve soyut anlamlandırma yeteneklerinin yetersizliğini göstermişlerdir (Makar ve Rubin, 2017). Bu 
sebeple birçok öğrencinin istatistik konularına karşı negatif tutum ve olumsuz hislerle yaklaştığ fark edilerek bunun en önemli nedenleri kullanılan geleneksel öğretim yöntemleri ve ölçmedeğerlendirme süreci olarak sıralanmıştır (Garfield ve Ahlgren, 1988; Garfield ve Gal, 1999). Günlük yaşamda istatistik okuryazarlığının ve bu okuryazarlığı değerlendirme araçlarının yetersizliği üzerinde düşünülmesi gereken konular olmuştur (Gal, 2002; Schield, 2004; Verhoeven, 2006). Bu açıdan bakıldığında matematik öğretiminde öğrenciyi değerlendirme süreci kapsamında öğrenciyi daha aktif kılan, örneğin, öğrencinin derse her gün hazırlıklı gelmesini sağlayan, etkili çalışma becerilerini geliştirmesine yardımcı olan portfolyo kullanımının (Burks, 2010) istatistik öğrenimine de benzer şekilde olumlu etki edeceği varsayılabilir. Portfolyo; araştırma ve inceleme, grup projesi raporu, gazete magazin makaleleri, öğrenci tarafından oluşturulan maketler, karmaşık matematiksel problem üzerine yapılan öğrenci çalışmasının karalama, düzeltilmiş ve son hallerini içermesi bakımından istatistik öğrenimine olumlu katkı sağlayabilir. Bilindiği üzere gazete makaleleri ve medya raporları kullanmak öğrencilerin çıkarım yapma yeteneklerinin ölçülmesine yardımcı olarak öğrencilerin istatistik konularını öğrenme heveslerini artırmaktadır (Pfannkuch, 2018). Ayrıca istatistiksel verilerin kullanıldığı günlük haberlerin (ör., nüfus sayımı, seçim sonuçları) öğrencilerin kritik düşünme becerilerini geliştirdiği gözlenmiştir (Tishkovskaya ve Lancaster, 2010).

Buna rağmen, literatürde portfolyo değerlendirmeve portfolyonun sınıf içi uygulamalarının ele alındığı oldukça sınırlı bir alan yazın mevcuttur (AlKhateeb, 2018; Crowley, 1993; Gencel, 2017; Ghoorchaei, Tavakoli ve Ansari, 2010; Nezakatgoo, 2011; Tiwari ve Tang, 2003). Ulusal alan yazına bakıldığında portfolyo değerlendirmesinin öğrencilerin matematik başarısı ve matematiğe karşı tutumu üzerine etkisini inceleyen sınırlı sayıda araştırma vardır (Abal1-Öztürk ve Şahin, 2014; Demirel, 2015; Gencel, 2017; Okçu, 2007; Özdemir ve Erdemci, 2017). Bu araştırma sonuçları büyük bir çoğunluğu portfolyoların matematik dersine ilişkin öğrenme ve anlamalarına istatistiksel olarak anlamlı etki ettiğini göstermiş (Abalı-Öztürk ve Şahin, 2014; Aktay ve Gültekin, 2014) ve öğrencilerin portfolyo hazırlamada yaşadıkları güçlüklere de dikkat çekmiştir (Okçu, 2007).

$\mathrm{Bu}$ çalışmanın amacı ortaokul matematik derslerinde portfolyo değerlendirmesinin7. sınıf öğrencilerinin istatistik başarısı üzerine etkisini incelemektir.

\section{Araştırma problemi}

Portfolyo değerlendirmesinin ilköğretim 7. sınıf öğrencilerinin istatistik başarısı üzerinde istatistiksel olarak anlamlı bir etkisi var mıdır?

\section{Alt problemler}

1. Portfolyo değerlendirmesinin kullanıldığı deney grubu öğrencileri ile mevcut öğretim programında yer alan değerlendirme sorularının kullanıldığı kontrol grubu öğrencilerinin, öntest ortalama puanları arasında istatistiksel olarak anlamlı bir fark var mıdır?

2. Portfolyo değerlendirmesinin kullanıldığı deney grubu öğrencilerinin, öntest ve sontest ortalama puanları arasında istatistiksel olarak anlamlı bir fark var mıdır?

3. Mevcut öğretim programında yer alan değerlendirme sorularının kullanıldığı kontrol grubu öğrencilerinin, öntest ve sontest ortalama puanları arasında istatistiksel olarak anlamlı bir fark var midir?

4. Portfolyo değerlendirmesinin kullanıldığ deney grubu öğrencileri ile mevcut öğretim programında yer alan değerlendirme sorularının kullanıldığı kontrol grubu öğrencilerinin, cinsiyet ve öntest toplam puanları kontrol altına alındığında, sontest düzeltilmiş ortalama puanları arasında deney grubu lehine istatistiksel olarak anlamlı bir fark var mıdır?

5. Portfolyo değerlendirmesinin kullanıldığı deney grubu öğrencileri ile mevcut öğretim programında yer alan değerlendirme sorularının kullanıldığı kontrol grubu öğrencilerinin, kazanç puanları (sontest puanı - öntest puanı) arasında istatistiksel olarak anlamlı bir fark var midir?

\section{Yöntem}




\section{Araştırma deseni}

Portfolyo değerlendirmesinin, 7. sinıf öğrencilerinin istatistik başarısı üzerine etkisini belirleyebilmek için öntest-sontest kontrol gruplu yarı deneysel desen kullanılmıştır (Fraenkel, Wallen ve Hyun, 2014). Bu desen bağımsız değişken etkisinde kalan deney grubu ve bağımsız değişken etkisine maruz kalmayan kontrol grubunu içerir. Deney ve kontrol grubu katılımcıları tam olarak rastgele atanamaz. Bu çalışmaya katılan sınıflar okul idaresi tarafından belirlenmiştir. Bu sinıflar araştırmacılar tarafından rastgele deney ve kontrol grubu olarak atanmıştır. Uygulama sürecinde dersler deney grubunda portfolyo değerlendirmesi ile, kontrol grubunda ise mevcut öğretim programında yer alan etkinliklere paralel olarak işlenmiştir. Katılımına resmi izin verilen seçilmiş sınıflarda eğitim-öğretim aynı matematik öğretmeni tarafından yürütülmektedir. Deney ve kontrol grubuna ders veren/uygulayıcı matematik öğretmeni alanında 30 y1lın üzerinde deneyime sahip bir öğretmendir. Değişen matematik eğitim programları üzerine bakanlık eğitimlerine katılmış; her sene farklı kademelerde öğretmen adaylarının yetişmesinde katkıda bulunmuştur. Deney ve kontrol gruplarının öntest puanları arasında anlamlı bir farklılık yoksa her iki grubun birbirine denk olduğu söylenebilir (Gay ve Airasian, 2000). Daha sonra, her iki grubun öntestten sonteste değişim gösteren puanları bağımlı değişken üzerinde anlamlı bir farkın olup olmadığını belirlemek üzere karşılaştırılır (Gay ve Airasian, 2000). Bu çalışmanın bağımlı değişkeni istatistik başarısı; bağımsız değişkeni ise portfolyo değerlendirmesidir. Bu bağlamda, deney ve kontrol grubu katılımcıları denel işlemler öncesi ve sonrasında bağımlı değişken ile ilgili ölçüldükleri için ilişkili desen, farklı deneklerden oluşan deney ve kontrol grubu katılımcılarının ölçüm sonuçları karşılaştırıldığ için ilişkisiz desen kullanılmıştır (Büyüköztürk, 2012). Tablo 1 'de çalışmanın modelinin deneysel deseni sunulmuştur.

Tablo 1.

Araştırmada Kullanılan Desenin Simgesel Gösterimi

\begin{tabular}{|c|c|c|c|c|}
\hline & Gruplar & $\begin{array}{c}\text { Uygulamadan Önce } \\
\text { Öntest }\end{array}$ & Uygulama Süreci & $\begin{array}{c}\text { Uygulamadan Sonra } \\
\text { Sontest } \\
\end{array}$ \\
\hline ROÖ $^{a}$ & Deney & $\mathrm{I}_{\mathrm{IBT}}^{\mathrm{b}}$ & Portfolyo değerlendirmesi & İBT \\
\hline ROÖ & Kontrol & İBT & $\begin{array}{l}\text { programında yer alan } \\
\text { etkinliklerin kullanıldığ } \\
\text { yöntem }\end{array}$ & İBT \\
\hline
\end{tabular}

aRastgeleOlmayan Örneklem.

bìstatistik Başarı Testi.

\section{Araştırma grubu}

Araştırmanın katılımcılarını İstanbul ili Fatih ilçesinde bulunan bir ortaokulda öğrenimine devam etmekte olan 7. sınıf öğrencileri oluşturmaktadır (Tablo 2). Okul idaresi tarafından rastgele dağılım esasına dayalı oluşturulan şubeler, araştırmacılar tarafından deney ve kontrol grubu şeklinde tesadüfi olarak belirlenmiștir. Deney grubunda 32, kontrol grubunda 32 olmak üzere toplam 64 öğrenci ile çalışılmıştır. Tablo 2'de katılımcıların grup ve cinsiyete göre dağılımı yer almaktadir.

Tablo 2.

Öğrencilerin Grup ve Cinsiyete Göre Dağıllımı

$\begin{array}{ccccc}\text { GRUP } & \text { KIZ } & \text { ERKEK } & \sum N & \% \\ & \mathrm{~N} & \mathrm{~N} & \sum^{2} & 50\end{array}$




\begin{tabular}{llccc} 
Kontrol & 17 & 15 & 32 & 50 \\
TOPLAM & 30 & 34 & 64 & 100 \\
\hline
\end{tabular}

Tablo 2 incelendiğinde cinsiyetin deney ve kontrol gruplarına göre dağılımı birbirine denktir.

\section{Veri toplama araçları}

7. sınıf matematik öğretim programında (MEB, 2018) 6. Ünite olan Veri Analizi konusunda öğrencilerin dersteki başarısını ölçmek üzere birinci araştırmacı tarafından geliştirilen İstatistik Başarı Testi (IBT) öntest ve sontest olarak deney ve kontrol gruplarına uygulanmıştır.

İstatistik başarı testi: İBT testi 10 adet açık uçlu sorudan oluşmaktadır (örnek soru için bkz. Şekil 1). Testin geliştirilme aşamasında her bir test maddesi öncelikle Bloom Taksonomisi'ne (Bloom ve diğerleri, 1956) göre düşük ve üst zihinsel süreçlerdeki bilgi ve becerileri ölçecek şekilde hazırlanmıştır. Test açık uçlu gerçek yaşam (madde 1 ve 2), merkezi eğilim ve yayılım ölçüleri sorularından (madde 3, 4, 5, ve 7), gösterilen verilere ilişkin durumları yorumlayıcı (madde 6, 8, ve 9) sorulardan ve grafik çizme (madde 10) sorularından oluşmaktadır. Testten alınacak puanlar 100 (en yüksek) ve 0 (en düşük) arasında değişmektedir. Testin değerlendirmesi aşağıdaki şekilde yapılmıştır:

- Matematiksel hesaplamaları doğru yapabilme (10 puan)

- Merkezi eğilim ve yayılım ölçülerini doğru seçebilme (10 puan)

- Verilen istatistikî durumlara yorum/açıklama/gerekçelendirme yapabilme (10 puan)

$\bullet$

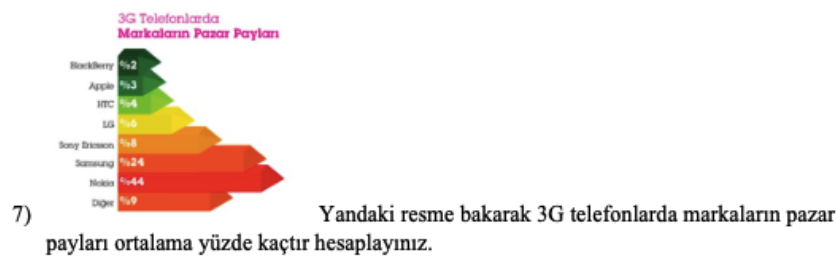

Şekil 1. İBT örnek soru

Öncelikle geliştirilen İBT testinin geçerliği ve güvenilirliği belirlenmeye çalışılmıştır. Testin içeriğini değerlendirmek üzere test belirtke tablosunun (O’Neil ve Schacter, 1997) içeriği ve bilişsel elemanları uygulamada olan matematik öğretim programına paralel olarak yapılandırılmıştır. Veri analizi alt öğrenme alanında öğrenci bilgi ve becerisini ölçmek üzere hazırlanan İBT'nin her bir maddesi test maddesi ve matematik öğretimprogramı ile uyumluluğu bağlamında değerlendirilmiştir. Bu değerlendirmeler konu kapsamının derinliği veya bilişsel düzeyleri (Sireci ve Faulkner-Bond, 2014) gözetilerek aynı zamanda matematik alan uzmanları ile birlikte yorumlanmıştır.

Kapsam geçerliği için İBT okulun üç farklı matematik öğretmenine gösterilmiştir. IBT'deki sorular matematiksel içerik bağlamında her bir öğretmen tarafından değerlendirilmiş ve sinıf düzeyine uygun bulunmuştur. Öğretmenlerin dönütleri göz önünde bulundurularak birkaç soru kökünde düzeltme yapılmıştır. Öğretmenler, öğrencilerin sadece işlemsel bilgilerini değil, akıl yürütme, kritik düşünme, gerekçelendirme becerilerini de ölçmenin doğru olacağını önermişlerdir. Bu bağlamda, örneğin, 4. ve 6. sorularda verilenleri kullanarak işlemlerin sonucunu açıkladıktan sonra öğrencilerden bu açıklamalarını "Neden?" ve "Niçin?" sorularına cevap verecek şekilde genişletmeleri istenmiştir. Benzer biçimde, öğretmenler tarafından öğrencilerde kafa karışıklığı yaratabileceği düşünülen soru içeriklerinde ek düzenlemeye gidilmiştir. Örneğin, 8. soru içeriğinde yer alan görsel birebir gazeteden alındığından, öğrencilerin veri okumada güçlük çekmemesi için soru kökü sonuna "Her bir ay için en yüksek değeri referans alınız" açıklaması eklenmiştir. Yapılan düzeltmeleri takiben İBT'nin düzenlenen son şeklini 
araştırmacılar ile birlikte Matematik ve Fen Eğitimi Bölümü'nde görev yapmakta olan ilköğretim matematik eğitimi alanında uzman bir profesör değerlendirmiştir.

Testin güvenirliğini ölçmek üzere pilot çalışma yapılmıştır. Pilot uygulamaya deney ve kontrol grubu olarak seçilen sınıflardan farklı, iki 7. sınıf rastgele olarak atanmıştır $(\mathrm{N}=50)$. İBT'den alınan toplam puanların Cronbach Alfa güvenirlik katsayısı .62 olarak bulunmuştur ( $\alpha \geq$ .66 en düşük makul limit, Krippendorff, 2004, sf. 241). Nunally (1967)'ye göre pilot çalışmalarda .50 - .60 arası uygulanabilir düzeydedir. Benzer şekilde, Rudner ve Schafer (2002), sınıf-içi başarı testlerinin $.50-.60$ arasında bir güvenirlik katsayısına sahip olmasının kabul edilebileceğini belirtmiştir. Ana çalışma için testin güvenirliği .80 olarak hesaplanmıştır. Büyüköztürk (2010) .70 'ten büyük olan katsayı değerlerinin testin güvenilir olduğuna işaret ettiğinin altını çizmektedir. Bu doğrultuda İBT denel işlem öncesi ve sonrasında deney ve kontrol gruplarına uygulanmıştır. Test süresi bir ders saatidir (40 dk).

\section{Denel işlemler}

Matematik öğretim programında veri analizi ünitesi dört temel kazanımı içermektedir: (M.7.4.1.1.) Verilere ilişkin çizgi grafiği oluşturur ve yorumlar; (M.7.4.1.2.1.) Bir veri grubuna ait ortalama, ortanca ve tepe değeri bulur ve yorumlar; (M.7.4.1.3.) Bir veri grubuna ilişkin daire grafiğini oluşturur ve yorumlar; ve (M.7.4.1.4.) Verileri sütun, daire veya çizgi grafiği ile gösterir ve bu gösterimler arasında uygun olan dönüşümleri yapar. Bu ünite 15 ders saatini kapsamakta ve tüm programın \%8'ini oluşturmaktadır (MEB, 2018).

Ancak bu çalışma, portfolyonun bir ölçme-değerlendirme yöntemi olarak kullanımının öğrencilerin veri analizi konusundaki başarına etkisi üzerine tasarlandığından 3 haftanın yeterli olamayacağı fark edilmiştir. Matematik öğretmeninin de aynı görüşü paylaşması ile 6 hafta boyunca (haftada 5 saat) toplam 30 ders saatinde veri analizi konusu işlenerek öğrencilerin bu süreçte kazandığ 1 yeni bilgi ve beceriler portfolyo ile değerlendirilmiştir. Deney ve kontrol gruplarında paralel olarak yürütülen konular her iki grupta eş zamanda bitirilmiştir. Uygulama süreci Tablo 3 'te detaylı olarak yer almaktadır.

\section{Deney grubunda gerçekleştirilen işlemler}

Deney grubunda uygulanan portfolyo değerlendirmesi için kullanılan veri analizi konu içerikleri ve bu kapsamda öğrencilerden istenen görevlerin ayrıntıları Tablo 4'te sunulmuştur.

Tablo 3.

Deney ve Kontrol Gruplarında İşlenen Veri Analizi Konusu Zaman Çizelgesi

\begin{tabular}{|c|c|c|}
\hline Haftalar & Deney Grubu & Kontrol Grubu \\
\hline 1. Hafta & $\begin{array}{l}\text { Ön Test (İBT) Uygulaması } \\
\text {-Verilere ilişkin çizgi grafiği çizme ve } \\
\text { çizilen grafiği yorumlama. } \\
\text {-ìki veri grubuna ilişkin grafiği çizme } \\
\text { ve çizilen grafiği yorumlama. } \\
\text {-Portfolyo Hazırlama Görev } 1\end{array}$ & $\begin{array}{l}\text { Ön Test (İBT) Uygulamasi } \\
\text {-Verilere ilişkin çizgi grafiği çizme ve } \\
\text { çizilen grafiği yorumlama. } \\
\text {-İki veri grubuna ilişkin grafiği çizme } \\
\text { ve çizilen grafiği yorumlama. } \\
\text {-Matematik ders kitabında yer alan } \\
\text { ölçme-değerlendirme etkinliklerini } \\
\text { uygulama }\end{array}$ \\
\hline 2. Hafta & $\begin{array}{l}\text {-Verilere ilişkin oluşturulan grafikleri } \\
\text { inceleme ve yanlış yorumlamalara yol } \\
\text { açan çizgi grafikleri üzerine tartışma. } \\
\text {-Portfolyo Hazırlama Görev } 2\end{array}$ & $\begin{array}{l}\text {-Verilere ilişkin oluşturulan grafikleri } \\
\text { inceleme ve yanlış yorumlamalara yol } \\
\text { açan çizgi grafikleri üzerine tartışma. } \\
\text {-Matematik ders kitabında yer alan } \\
\text { ölçme-değerlendirme etkinliklerini } \\
\text { uygulama }\end{array}$ \\
\hline 3. Hafta & $\begin{array}{l}\text {-Belli bir veri grubuna ait ortalama, } \\
\text { ortanca ve tepe değerlerini bulma ve bu } \\
\text { değerleri yorumlama. }\end{array}$ & $\begin{array}{l}\text {-Belli bir veri grubuna ait ortalama, } \\
\text { ortanca ve tepe değerlerini bulma ve bu } \\
\text { değerleri yorumlama. }\end{array}$ \\
\hline
\end{tabular}




\begin{tabular}{|c|c|c|}
\hline & -Portfolyo Hazırlama Görev 3 & $\begin{array}{l}\text {-Matematik ders kitabinda yer alan } \\
\text { ölçme-değerlendirme etkinliklerini } \\
\text { uygulama }\end{array}$ \\
\hline 4. Hafta & $\begin{array}{l}\text { - Belli bir veri grubuna ait ortalama, } \\
\text { ortanca ve tepe değerlerinden hangisinin } \\
\text { daha kullanışlı olduğunu anlama. } \\
\text {-Ortalama, ortanca ve tepe değerlerini } \\
\text { anlamaya yönelik çalışmalar } \\
\text { kapsamında bilgi ve iletişim } \\
\text { teknolojilerini kullanma. } \\
\text {-Portfolyo Hazırlama Görev } 4\end{array}$ & $\begin{array}{l}\text { - Belli bir veri grubuna ait ortalama, } \\
\text { ortanca ve tepe değerlerinden hangisinin } \\
\text { daha kullanışli olduğunu anlama. } \\
\text {-Ortalama, ortanca ve tepe değerlerini } \\
\text { anlamaya yönelik çalışmalar } \\
\text { kapsamında bilgi ve iletişim } \\
\text { teknolojilerini kullanma. } \\
\text {-Matematik ders kitabında yer alan } \\
\text { ölçme-değerlendirme etkinliklerini } \\
\text { uygulama }\end{array}$ \\
\hline 5. Hafta & $\begin{array}{l}\text {-Verilere iliş̧kin daire grafiği çizme ve } \\
\text { çizilen grafiği yorumlama. } \\
\text {-Portfolyo Hazırlama Görev } 5\end{array}$ & $\begin{array}{l}\text {-Verilere ilişkin daire grafiği çizme ve } \\
\text { çizilen grafiği yorumlama. } \\
\text {-Matematik ders kitabında yer alan } \\
\text { ölçme-değerlendirme etkinliklerini } \\
\text { uygulama }\end{array}$ \\
\hline 6. Hafta & $\begin{array}{l}\text {-Verilere ilişkin sütun, daire veya çizgi } \\
\text { grafiği çizme ve çizilen grafiği } \\
\text { yorumlama. } \\
\text {-Çizilen grafiklerin gösterimleri } \\
\text { arasında uygun olan dönüşümleri } \\
\text { yapma ve bu gösterimler arasında ilişki } \\
\text { kurma. } \\
\text {-Portfolyo Hazırlama Görev } 6 \\
\text { Son Test (IBTT) Uygulaması }\end{array}$ & $\begin{array}{l}\text {-Verilere ilişkin sütun, daire veya çizgi } \\
\text { grafiği çizme ve çizilen grafiği } \\
\text { yorumlama. } \\
\text {-Çizilen grafiklerin gösterimleri } \\
\text { arasında uygun olan dönüşümleri } \\
\text { yapma ve bu gösterimler arasında ilişki } \\
\text { kurma. } \\
\text {-Matematik ders kitabında yer alan } \\
\text { ölçme-değerlendirme etkinliklerini } \\
\text { uygulama } \\
\text { Son Test (IBT) Uygulaması }\end{array}$ \\
\hline
\end{tabular}

Tablo 4.

Örnek Uygulama: Portfolyo Hazırlama Süreci

Hafta İçerik*

1. Hafta Ders: Çizgi grafiği oluşturma ve yorumlama. İki veri grubuna ait grafik oluşturma.

Görev 1: 6. sınıfta istatistik ünitesinde neler öğrendiniz? Bu dönem 7. sinıfta bu ön bilgilerinize neler eklediniz? 8. sinıfta istatistik ünitesinde neler öğrenmeyi bekliyorsunuz? Bu sorulara cevap verecek bir paragraf yazmak.

2. Hafta Ders: Yanıltıcı grafikler ve yanlış yorumlamalara yol açan çizgi grafiklerini inceleme

Görev 2: Matematik otobiyografisi yazmak: Çocukken matematiği nasıl öğrendiniz? Matematiği ilk ne zaman öğrenmeye başladınız? İstatistik size ne ifade ediyor? İstatistik hakkındaki genel düşünceniz nedir? Hangi istatistik konusunu en iyi öğrendiniz? Bu sorulara cevap verecek bir düz yazı yazmak. Ek olarak, ders süresince örnek sorular içeren test sorularını, ödevleri, sınıf içi mini sınavları biriktirmek. Öğretmenin uyguladığı bu sorulardan en başarılı olanlarını seçip çalışma sonunda portfolyoya eklemek.

3. Hafta Ders: Veri grubuna ait ortalama, ortanca ve tepe değerini bulma ve yorumlama.

Görev 3: İstatistik ünitesinde öğrendiği 8. sınıfta kendilerine gerekli/faydalı olacağını düşündükleri yeni terimler ile ilgili tablo hazırlamak. 
4. Hafta Ders: Belli bir veri grubu için ortalama, ortanca ve tepe değeri gibi değerlerden hangisinin daha kullanışlı olduğunu anlamaya yönelik çalışmaları bilgi ve iletişim teknolojileri kullanarak yürütme. Günlük yaşam örneklerini (örn., gazete, dergi, televizyon, beyaz eşya kılavuzlarından istatistiki örnekler) sinıfta paylaşma.

Görev 4: Öncelikle sınıfın 6 gruba ayrılması istenmiştir. Her bir grubun veri analizi konusunda işbirlikli çalışma yapması ve öğrendiklerini uygulaması beklenmiştir. (Bkz Şekil 2)

5. Hafta Ders: Bir veri grubuna ilişkin daire grafiğini oluşturma ve yorumlama. Görev 5: 4. Haftada öğrencilere verilen Görev4'te açıklanan ödevler öğretmen ve araştırmacı tarafından tekrar değerlendirilmiştir. Derecelendirme puanlama anahtarına (rubrik) göre ikinci geri bildirimler verilmiştir. Bu geri bildirimlere göre ödevi düzenleyip portfolyo içeriğine eklemek.

6. Hafta Ders: Verileri sütun, daire veya çizgi grafiği ile gösterme ve bu gösterimler arasinda uygun olan dönüşümleri yapma.

Görev 6: Öğrenci kitabının arkasında verilen istatistik ünitesi ile ilgili değerlendirme çalışmalarını yapmak ve rapor yazmak. İlgi duydukları bir konu üzerine veri toplama ve bu veri grubu üzerine üç boyutlu (3D) modelleme yapmak. Öğretmen tarafından verilen Öz-Değerlendirme Formunu doldurmak. Öğretmene ve araştırmaciya konu ve portfolyo hazırlama süreci ile ilgili herhangi bir yorumu ve geri bildirimi varsa bunu iletmek. Tüm ürünleri portfolyoya eklemek.

* Öğrenciler 2., 3., 4., ve 5. Haftalarda bir önceki haftada verilen dönütlere göre portfolyo içeriğinde düzeltme yapma görevini yerine getirmişlerdir.

Uygulama süreci matematik öğretmeni rehberliğinde yürütülmüştür. Başarı testinin hazırlanması ve uygulanması ile portfolyo içeriğinin hazırlanması ve uygulanması aşamasında tüm adımlarda öğretmenin görüşleri alınmıştır. Bu süreç, aynı zamanda birinci araştırmacı tarafından da takip edilerek, uygulamanın doğru ve verimli işlemesi için gerekli kontroller sağlanarak önlem alınmıştır. Deney grubu öğrencilerinin 1 . Hafta ve 2 . Hafta görevlerine verdiği cevaplardan örnekler aşağıda sunulmuştur:

"6. Sınıfta istatistiğin günlük yaşamımızdaki olaylarl ve durumlarl gösterdiğini ögrenmiştim. Bu şekilde anlayarak daha çabuk ve kolayca ögrenebiliriz. Bu sene grafikleri yorumlamayl, mod medyan hesaplamayl ve daire grafiğini ögrendim. Hem 6. sinifta öğrendiklerimi geliştirdim hem de yeni şeyler öğrendim. Seneye daha fazla grafik çeşitlerini ögrenmeyi, yeni grafikler çizmeyi ve 7. sinıfta öğrendiklerimi kullanabilmeyi istiyorum." (1. Hafta, Ögrenci A)

"Sayıları abaküste să̆dan sola saymaya başladım. Çocukluğumdan beri annem abimle matematik çalışırken ben de onları gözlerdim ve matematiği ilk böyle tanıdım. İstatistiğin yaşamımızın birçok anında hayatımızı kolaylaştırdığını düşünüyorum. İstatistiği, bir konuyu göstermek, bir konuyu veya çalışmayı grafikle belirtmek için kullanabiliriz. Istatistik konuları içerisinde en iyi sütun grafiğini öğrendiğimi düşünüyorum." (2. Hafta, Ögrenci D)

3. Hafta görevi için oluşturdukları örnek bir tablo Şekil 2'de gösterilmiştir:

\begin{tabular}{lllll}
\hline 1.Aritmetik Ortalama & 2.Daire Grafiği & \multicolumn{2}{l}{ 3.Çizgi Grafiğ } & 4.Grafik yorumlama \\
\hline 5.Veri & 6.Araştırma & \multicolumn{2}{l}{ 7.Sütun Grafiği } & 8.Ortanca \\
\hline 9.Tepe Değer & $\begin{array}{l}\text { 10.Çok küçük } \\
\text { değerler }\end{array}$ & $\begin{array}{l}\text { 11.Çok büyük } \\
\text { değerler }\end{array}$ & 12.Uç değerler \\
\hline
\end{tabular}

Şekil 2. En sık kullanılan terimler tablosu 
4. Hafta ve 5. Hafta sinıf altı gruba ayrılarak öğrenciler Tablo 5'te gösterilen konuları içeren performans çalışmasına başlamıştır. Performans çalışmaları sürecinde öğrenci gelişimi ve performans kanıtları saptanırken iş birlikli öğrenme, grup çalışması, günlük hayat durumlarına yer verme, araştırma yapma ve sunma, öz değerlendirme, yansitıcı rapor yazdırma vb. (Kan, 2007; Polat-Demir ve Kutlu, 2016; Yanpar-Yelken, 2009) yöntemler de dâhil edilmiştir. Aynı zamanda, öğretim sürecinde bir veri grubuna ilişkin daire grafiğini oluşturup yorumlamışlardır. Öğrencilere her bir performans çalışmasının amacı, kullanabilecekleri materyaller ve dikkat edilmesi gereken önemli hususlar araştırmacı tarafından öğrencilere açıklanmıştır (bkz Tablo 5).

Tablo 5.

Sınıf içi Gruplara Dağıtılan Görevler

\begin{tabular}{l} 
Gruplar: Görevler ve Kazanımlar \\
\hline Grup 1: Grafik Yorumlama \\
Ögrrenciler, yanlış bir şekilde temsil edilen \\
bilgileri, tüketicileri aldatmaya yönelik olarak \\
hazırlanan yanıltıcı grafikleri istatistik yardımıla \\
sorgular. (Değerlendirme, Bilişsel)
\end{tabular}

Grup 2: Çizgi Grafiği

Öğrenciler, bir istatistik araştırmasında iş birlikli bir şekilde gruplar halinde çalışır. (Sentez, Duyuşsal)
- Araba fiyat ortalaması verilen iki grafiğin farklılığın nedenlerini açıklayınız

- Hangi grafik yanıltıcı grafiktir? Cevabınızı açıklayınız.

- Yaniltıc1 grafik neden kullanılır?

- Sinıftaki arkadaşlarınızın iki ayrı sınav sonucunu seçerek sütun ve çizgi grafiği ile gösteriniz.

- Grafiği hangi kritere göre çizdiğinizi açıklayınız.

- Ortalama, ortanca, tepe değeri, açılık, alt ve üst çeyrekleri bulunuz.

Grup 3: Sinıf Ropörtaj1

Öğrenciler, günlük hayattan verilen durumlarla ilgili grafik çizer. (Uygulama, Psikomotor)

- Arkadaşlarınızın boy ve kilolarını tablolayınız.

- Sonuçları daire veya sütun grafiğiyle gösteriniz.

- Hangi grafiği türünü neden seçtiğinizi açıklayınız.

\begin{tabular}{c} 
Gruplar: Görevler ve Kazanımlar \\
\hline Grup 4: İstatistiğin Günlük Hayatımızdaki Yeri
\end{tabular} Öğrenciler, istatistiğin kullanım alanları ile ilgili araştırma yapar. (Analiz, Bilişsel)
İçerik

- İstatistik hangi alanlarda kullanılır araştırarak örnek ve resimler bulunuz.

- Gazete araştırması yapınız. İstatistik bu alanlara ne gibi katkı yapıyor yazınız.

- Araştırmanızı arkadaşlarınıza sınıfta sununuz.
Grup 5: Yanıltıcı Grafikler

Öğrenciler, şimdiki ve gelecek durumlarla ilgili verilere ilişkin tahmin ve çıkarımlar yapabilecek. (Değerlendirme, Bilişsel)

- Ali'nin y1llara göre verilen kütle değişim grafiğini (kütle/yıl) inceleyiniz.

- Hangi grafik yanlış yorumlamaya neden olur açıklayınız.

- Ali'nin kütlesindeki değişimi inceleyerek gelecekteki kütlesini tahmin ediniz.

Grup 6: Kendinizi Değerlendirin
- Bir hafta boyunca yaptığınız aktiviteleri değerlendirin: Ne kadar 


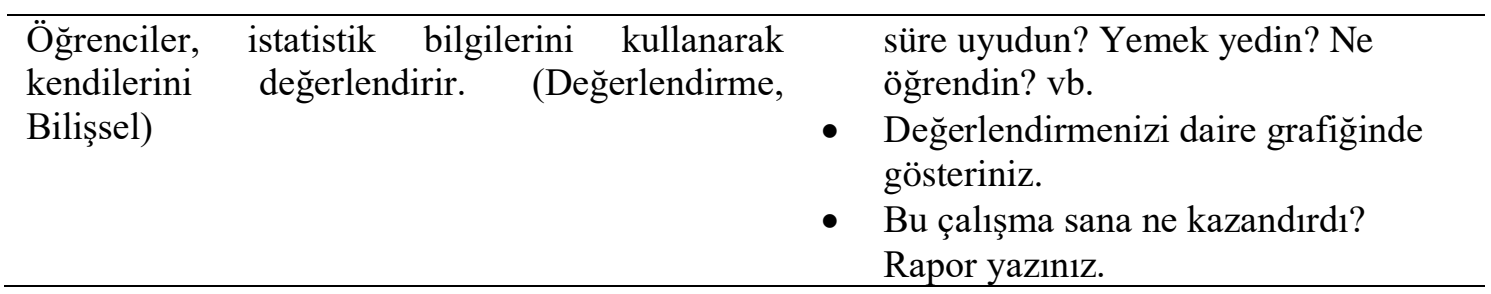

Son olarak, 6. Hafta ilgi duydukları bir konu üzerine veri toplama ve bu veri grubu üzerine üç boyutlu (3D) modelleme yapan öğrencilerin yaratıcılık ve hayal güçlerini kullanarak tasarladıkları örnek maketler Şekil 3'de sunulmuştur.
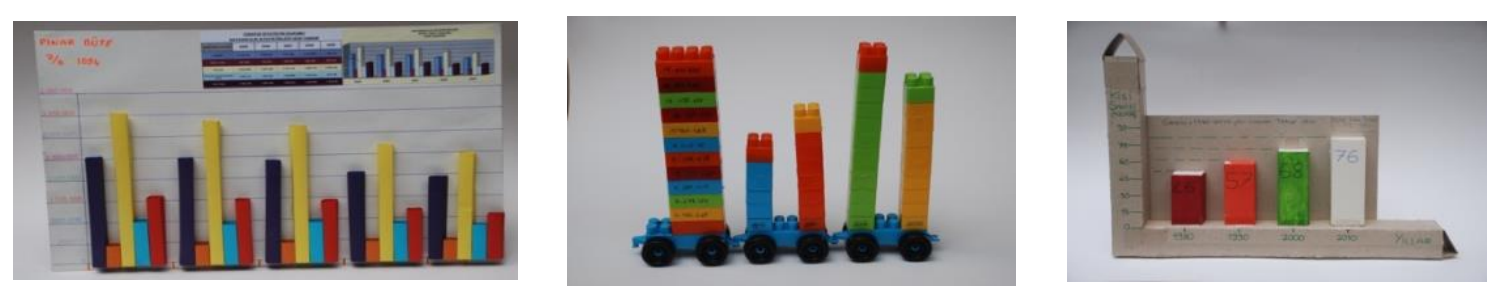

Şekil 3. Veri analizi 3D modelleme örnekleri

Genel olarak, öğrencilerin maketlerini daha çok renkli karton kullanarak tasarladıkları ve istatistik kavramını sütun ve daire grafikleri ile özdeşleştirerek ifade ettikleri görülmüştür (bkz Şekil 4).

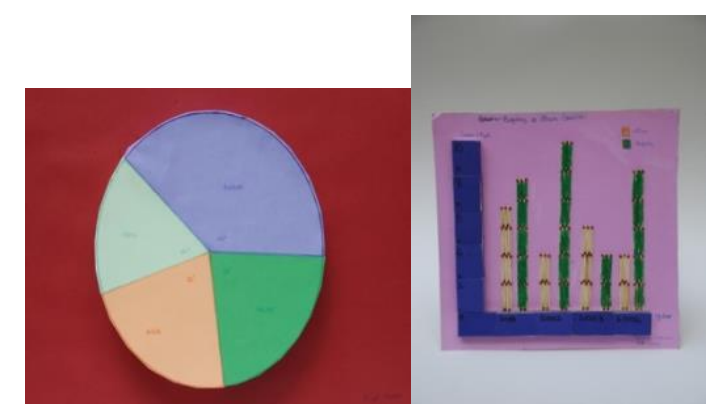

Şekil 4. Daire ve sütun grafiği tasarımı

Ek olarak, öğrencilerin portfolyolarına doldurarak koydukları Öz-Değerlendirme Formu'na ilişkin örnekler Şekil 5'te sunulmuştur (Form MEB 7. sınıf kitabının ünite sonu özdeğerlendirme bölümünden alınmıştır). Tablo ve grafikler, merkezi eğilim ve yayılım ölçüleri konularında bilgiyi anlama ve yorumlama becerilerinde öğrencilerin kendine güvenlerinin olduğu görülmektedir. Grafik çeşitlerini fark edebilme, tüketiciyi yanıltabilecek grafikleri belirleme ve değerlendirme yapmayı öğrendikleri görülmektedir. Grafik çeşitlerini ve özelliklerini ayırt etmeye başladıkları ve bu konudaki öz farkındalıklarının geliştiği görülmüştür (bkz Şekil 5). Sınıfın büyük çoğunluğu veriye dayalı tahmin yürütme konusunda da kendilerine ortalama 3 vermiştir (Yetersiz $=1$, Orta $=2$, İyi $=3$, Çok İyi $=4)$. Portfolyolara verilen son dönüt olarak ise bazı öğrencilerden detaylı rapor yazmaları; bazılarından herkesin kendi görevini anlattı̆̆ grup araştırması raporu hazırlaması ve bazı öğrencilerden de hazırladıkları grafikleri daha görsel renkli hale getirmeleri istenmiştir.

\section{Kontrol grubunda gerçekleştirilen işlemler}

Kontrol grubunda dersler eğitim/öğretim yılının başında veri analizi konusunda hazırlanan ders planlarına paralel olarak aynı matematik öğretmeni tarafından mevcut öğretim programında yer alan etkinlikler kullanılarak işlenmiştir. Ders boyunca öğretmen sınıfa veri analizi konusunda 
bilgiyi aktarmıştır. Daha sonra öğrenciler öğrendikleri yeni istatistik kavramları, sembolleri ve yöntemleri kullanarak soru çözmüşlerdir. Dolayısıyla, süreç boyunca matematik ders kitabının (MEB, 2018) önerdiği ölçme-değerlendirme teknikleri, örnekler, etkinlikler ve değerlendirme soruları kullanılmıştır. 6 hafta sonunda kontrol grubunun öğretimi tamamlanmıştır.

Veri analizi konusu anlatımı ve ölçme-değerlendirme süreci tamamlandıktan sonra öğrenci başarılarının nasıl değiştiğini belirlemek için deney ve kontrol gruplarına İBT sontest olarak uygulanmıştır.

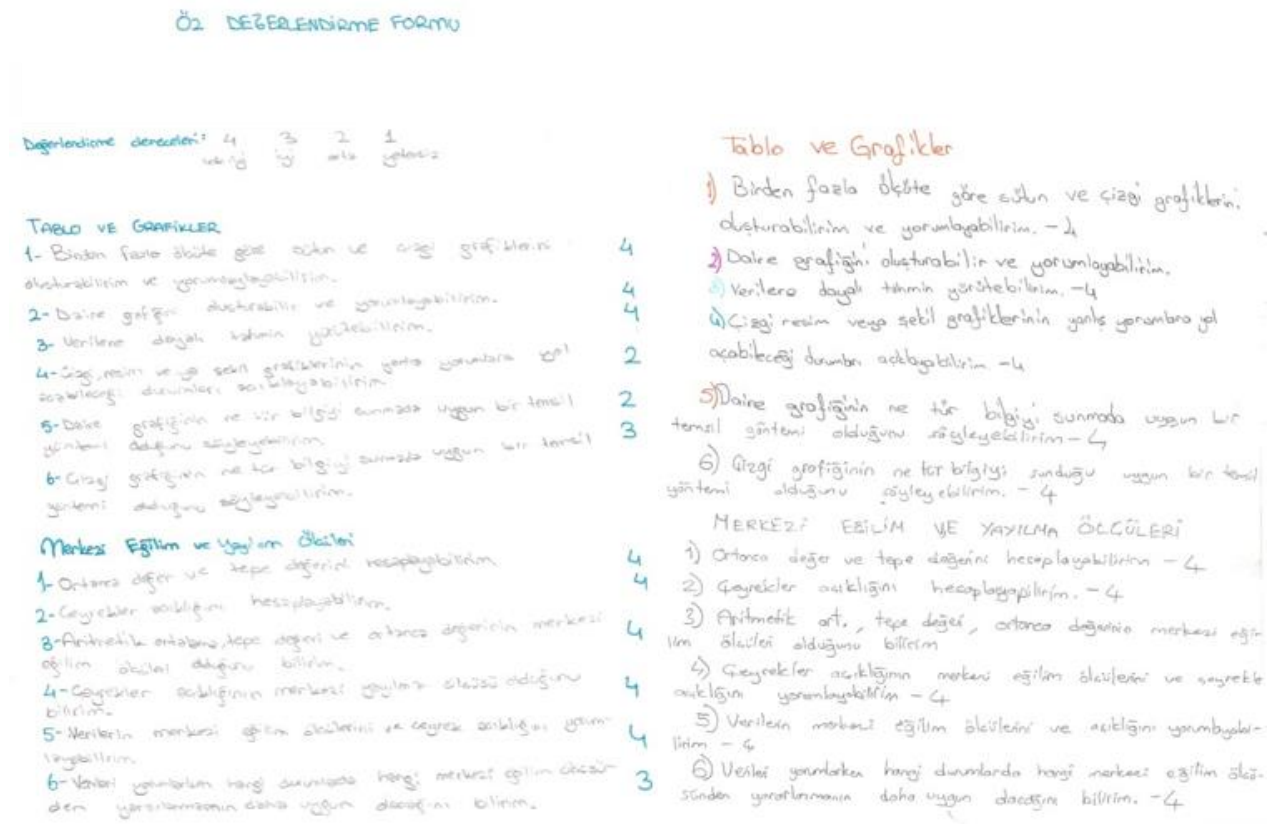

Şekil 5. Öz-değerlendirme formlarından örnekler

\section{Verilerin analizi}

Araştırmanın veri kaynakları öğrencilerin İBT'den aldıkları öntest ve sontest puanları ile cinsiyetlerini belirttikleri kişisel bilgilerdir. İBT puanlarının öntest ve sontest ortalamaları ile standart sapmaları deney ve kontrol grubu öğrencileri için ayrı ayrı hesaplanmıştır. Daha sonra, Kolmogorov-Simirnov Testi yürütülerek deney ve kontrol grubu öğrencilerinin öntest ve sontest IBT puanlarının normal dağılım gösterip göstermediği araştırılmıştır. Deney ve kontrol gruplarının öntest ortalamalarının birbirinden farklılaşıp farklılaşmadığını (Alt Problem 1) incelemek için İlişkisiz Örneklemler t-Testi yapılmıştır. Deney ve kontrol gruplarının öntest ve sontest ortalamalarının kendi içinde karşılaştııılması (Alt Problem 2 ve Alt Problem 3) amacıyla İlişkili Örneklemler t-Testi yapılmıştır. Öğrencilerin cinsiyetleri ve öntest puanları kontrol altına alındığında, sontest puanları arasında farklılaşma olup olmadığını (Alt Problem 4) incelemek için ise, Çift-Faktörlü Kovaryans (Two-Factor ANCOVA) analizi yapılmıştır. Büyüköztürk (2012), deneysel çalışmalarda ortak değişken (kovaryant) etkilerinin kaldırılmak istendiği zamanlarda ANCOVA kullanılmasını önermiştir. ANCOVA analizine geçmeden önce gerekli varsayımların sağlanıp sağlanmadığı incelenmiş ve tüm varsayımların sağlandığı tespit edildikten sonra kovaryant olarak cinsiyet ve öntest puanları analize sokulmuştur. Son olarak deney ve kontrol gruplarının öntest ve sontest toplam puanları üzerinden kazanç puanları (sontest puanı - öntest puanı) hesaplanarak yeni bir değişken - Kazanç Puanı (Gain Score/Gain Difference) oluşturulmuştur. Daha sonra deney ve kontrol gruplarının kazanç puan ortalamaları arasında istatistiksel olarak anlamlı bir fark olup olmadığını (Alt Problem 5) incelemek üzere İlişkili Örneklemler t-Testi yapılmıştır. Bu araştırmada yürütülen analizlerin (betimleyici ve açıklayıcı istatistikler) tümünde IBM SPSS 21.0 (SPSS, 2012) paket programı kullanılmıştır. Sonuçların yorumlanmasında anlamlılık düzeyi " $p=.05$ " olarak kabul edilmiştir. 


\section{Bulgular}

Deney ve kontrol grupları arasındaki denkliği incelemek üzere İlişkisiz Örneklemler t-Testi yürütülmüştür. Tablo 6'da elde edilen bulgular sunulmuştur.

Tablo 6.

Öntest İstatistik Başarısı Puanlarına İlişkin İlişkisiz Örneklemler T-Testi Sonuçları

\begin{tabular}{ccccccc}
\hline Grup & $\mathrm{N}$ & $\overline{\mathrm{X}}$ & $\mathrm{S}$ & $\mathrm{sd}$ & $\mathrm{t}$ & $\mathrm{p}$ \\
\hline Deney & 32 & 31.53 & 3.08 & 17.44 & 1.69 & .095 \\
Kontrol & 32 & 40.41 & 4.22 & 23.89 & & \\
\hline
\end{tabular}

Deney ve kontrol grubunda istatistik başarısı öntest puanlarına ait varyansların istatistiksel olarak anlamlı bir fark gösterip göstermediğini belirlemek için yapılan Levene's testi sonuçları gruplar arasında varyansın homojen olduğunu göstermiştir $(\mathrm{F}=8.863 ; \mathrm{p}=.054)$. Tablo 6 'da görüldüğü gibi, bağımsız gruplar için yapılan İlişkisiz Örneklemler t-testi sonuçları öntest istatistik başarı puanlarının deney $(\bar{X}=31.53$, sd $=17.44)$ ve kontrol $(\bar{X}=40.41, \mathrm{sd}=23.89)$ grubunda istatistiksel olarak anlamlı bir farklılık göstermediğini ortaya koymuştur $(\mathrm{t}(62)=1.69$, $p>.05$ ). Ortalamalar arasındaki fark küçüktür (ortalama farkı= 8.86, 95\% CI: -1.57 - 19.32). Ayrıca etki büyüklüğü hesaplanmış ve elde edilen değer Cohen (1988) kriterlerine göre küçük bulunmuştur $\left(\eta^{2}=.04\right)$. Bu sonuç, deney ve kontrol gruplarının uygulamaya başlamadan önce veri analizi konusundaki bilgilerinin birbirine denk olduğuna işaret etmektedir.

İBT'den elde edilen verilerin normal dağılım gösterip göstermediğini incelemek üzere yürütülen Kolmogorov Smirnov testinden elde edilen bulgular Tablo 7'de sunulmuştur.

Tablo 7.

Normal Dağılıma İlişkin Kolmogorov Smirnov Testi Sonuçları

\begin{tabular}{lcccc}
\hline & \multicolumn{2}{c}{ Deney } & \multicolumn{2}{c}{ Kontrol } \\
\hline & Öntest & Sontest & Öntest & Sontest \\
\cline { 2 - 5 } $\mathrm{N}$ & 32 & 32 & 32 & 32 \\
$\overline{\mathrm{X}}$ & 31.53 & 55.19 & 40.41 & 52.59 \\
$\mathrm{~S}$ & 3.08 & 3.79 & 4.22 & 3.38 \\
Kolmogorov Smirnov $(\mathrm{Z})$ & .079 & .124 & .167 & .165 \\
$\mathrm{p}$ & .200 & .200 & .240 & .270 \\
\hline
\end{tabular}

Tablo 7'ye göre deney ve kontrol grubuna uygulanan öntest ve sontest puanları istatistiksel olarak normal dağılım göstermektedir ( $p>.05)$. Dolayısıyla öğrencilerin İBT'den aldıkları öntest ve sontest puanları arasında istatistiksel olarak anlamlı bir fark olmadığ 1 söylenebilir. Bu sonuç bağlamında bir sonraki aşamada yürütülen analizlerde, öntest-sontest İBT puanlarını karşılaştırılmak üzere parametrik testlerden t-Testi ve ANCOVA kullanılmıştır.

Çalışmanın ana araştırma sorusu "Portfolyo değerlendirmenin istatistik başarısı üzerine etkisi nedir?"i incelemek üzere İBT deney ve kontrol grubuna öntest ve sontest olarak uygulanmıştır. Tablo 8'de deney ve kontrol grubu öğrencilerinin istatistik başarısına ait bulgular sunulmuştur.

Tablo 8 .

İstatistik Başarısına İlişkin Betimsel İstatistik Sonuçları

\begin{tabular}{ccccccc}
\hline \multicolumn{3}{c}{ Öntest } & $\mathrm{N}$ & Sontest \\
Grup & $\mathrm{N}$ & $\overline{\mathrm{X}}$ & $\mathrm{S}$ & 32 & 55.19 & $\mathrm{~S}$ \\
\hline Deney & 32 & 31.53 & 3.08 & 32 & 52.59 & 3.38 \\
Kontrol & 32 & 40.41 & 4.22 & & \\
\hline
\end{tabular}


Kontrol grubunda İBT öntest puan ortalamas1 40.41 iken, uygulama sonras1 İBT sontest puan ortalaması 52.59 olarak hesaplanmıştır. Portfolyo değerlendirmesinin kullanıldığı deney grubunda ise, IBT öntest puanı 31.53 iken, uygulama sonrası İBT sontest puan ortalamas1 55.19 olarak hesaplanmıştır. $\mathrm{Bu}$ doğrultuda, hem deney hem de kontrol grubunda sontest puan ortalamalarının öntest puan ortalamalarına göre yükseldiği görülmektedir. Tablo 8 incelendiğinde, deney grubunun sontest puan ortalamasının $(\bar{X}=55.19)$ kontrol grubu sontest puan ortalamasından $(\bar{X}=52.59)$ yüksek olduğu gözlenmektedir.

Deney grubunda yapılan uygulamanın istatistik başarı puanları üzerindeki etkisini belirlemek (Alt Problem 2) amacıyla yapılan İlişkili Örneklemler t-Testi sonuçları Tablo 9' da yer almaktadır. Elde edilen bulgular, öntest ve sontest İBT puanları arasında istatistiksel olarak anlamlı bir fark olduğunu ortaya koymuştur $(\mathrm{p}<.05)$.

Tablo 9.

Deney Grubuna Ait Öntest-Sontest İstatistik Başarısına İlişkin İlişkili Örneklemler T-Testi Sonuçları

\begin{tabular}{ccccccc}
\hline Grup & $\mathrm{N}$ & $\overline{\mathrm{X}}$ & $\mathrm{S}$ & $\mathrm{sd}$ & $\mathrm{t}$ & $\mathrm{p}$ \\
\hline Öntest & 32 & 31.53 & 3.08 & 17.44 & -10.13 & .00 \\
Sontest & 32 & 55.19 & 3.79 & 21.49 & & \\
\hline
\end{tabular}

Kontrol grubunda yürütülen uygulamanın istatistik başarı puanları üzerindeki etkisini belirlemek (Alt Problem 3) amacıyla yapılan İlişkili Örneklemler t-Testi sonuçları Tablo 10'da yer almaktadır. Benzer şekilde, elde edilen bulgular, öntest ve sontest İBT puanları arasında istatistiksel olarak anlamlı bir fark olduğuna işaret etmiştir $(\mathrm{p}<.05)$.

Tablo 10

Kontrol Grubuna Ait Öntest-Sontest İstatistik Başarısına İlişkin Ilişkili Örneklemler T-Testi Sonuçları

\begin{tabular}{ccccccc}
\hline Grup & $\mathrm{N}$ & $\overline{\mathrm{X}}$ & $\mathrm{S}$ & $\mathrm{sd}$ & $\mathrm{t}$ & $\mathrm{p}$ \\
\hline Öntest & 32 & 40.41 & 4.22 & 23.89 & -4.87 & .00 \\
Sontest & 32 & 52.59 & 3.38 & 19.16 & & \\
\hline
\end{tabular}

Grupların birbirine denk olduğu tespit edildikten sonra, portfolyo değerlendirmesinin kullanıldığı deney grubu öğrencileri ile mevcut öğretim programında yer alan değerlendirme sorularının kullanıldığı kontrol grubu öğrencilerinin, cinsiyet ve öntest toplam puanları kontrol altına alındığında, sontest düzeltilmiş ortalama puanları arasında deney grubu lehine istatistiksel olarak anlamlı bir fark olup olmadığını (Alt Problem 4) incelemek üzere uygulanan Çift-Faktörlü Kovaryans Analizi sonuçlarına geçmeden önce ANCOVA varsayımlarının (kovaryantların güvenirliği, kovaryantlar arası korelasyon, doğrusallık ve varyansların homojenliği) sağlanıp sağlanmadığı incelenmiştir. Bulgular verinin tüm varsayımları sağladığını göstermiştir. Ayrıntılı olarak ele alındığında, bağımsız değişken olarak analize katılan tüm kovaryantlar (cinsiyet ve öntest) ile bağımlı değişken (sontest) arasında istatistiksel olarak anlamlı bir ilişki vardır. Bu sonuçlara göre, cinsiyet $(r=.21, p<.05)$ ve öntest $(r=.71, p<.05)$ ortak değişkenlerinin sontest ile olan ilişkisi doğrusaldır. Ek olarak, Levene's Testi varyansların homojenliği varsayımı da sağlanmıştır. Sonuçlar gruplar arasında varyansın homojen olduğunu ortaya koyarak $(F=2.670$; $p=.056$ ) sontest puanlarının gözlenen kovaryans matrislerinin deney ve kontrol grupları için eşit olduğunu ortaya koymuştur. Deneklerarası Etkiler Testi'nden elde edilen bulgular grup, cinsiyet ve öntest arasındaki etkileşimin istatistiksel olarak anlamlı olmadığını göstermiştir, $F(2,58)=$ $.51, p=.59$ (> .05). Bu bağlamda, regresyon doğrularının homojenliği -regresyon doğrularının eğimleri eşittir- varsayımının sağlandığı tespit edilmiştir. 
Varsayımların tümünün sağlandığının tespit edilmesi sonrasında Çift-Faktörlü ANCOVA analizi yapılmıştır. Tablo 11'de grupların cinsiyetlerine ve öntest puanlarına göre düzeltilmiş sontest puan ortalamaları ve standart hataları ayrıntılı şekilde sunulmuştur.

Tablo 11

Düzeltilmiş Sontest Puanlarının Gruba Göre Kovaryans Analizi Sonuçları

\begin{tabular}{lcccccc}
\hline \multicolumn{1}{c}{$\begin{array}{c}\text { Varyans } \\
\text { Kaynağ }\end{array}$} & $\begin{array}{c}\text { Tip III Kareler } \\
\text { Toplamı }\end{array}$ & sd & $\begin{array}{c}\text { Kareler } \\
\text { Ortalamas1 }\end{array}$ & F & $\mathrm{p}$ & $\eta^{2}$ \\
\hline Cinsiyet & 7.666 & 1 & 7.666 & .045 & .833 & .001 \\
Öntest & 14095.348 & 1 & 14095.348 & 82.942 & $.000^{*}$ & .584 \\
Yöntem & 1303.320 & 1 & 1303.320 & 7.669 & $.007^{*}$ & .115 \\
Hata & 10026.592 & 59 & 169.942 & & & \\
Toplam & 211677.000 & 64 & & & & \\
\hline
\end{tabular}

Not. $R^{2}=.611$ (düzeltilmiş $R^{2}=.585$ ). ${ }^{*} p<.05$.

Bulgular cinsiyet ve öntest puanları kontrol altına alındığında portfolyo değerlendirmesinin istatistiksel olarak anlamlı bir fark yarattığına işaret etmektedir $(F(1,59)=$ $7.669, p=.007)$. Diğer bir deyişle, deney ve kontrol gruplarının cinsiyet ve öntest puanlarına göre düzeltilmiş sontest puan ortalamaları bakımından portfolyo değerlendirmesi anlamlı bir farklılaşma oluşturmuştur. Betimsel analiz sonuçlarının da gösterdiği üzere, ortaya çıkan bu farklılık deney grubunun lehinedir (bknz. Tablo 8). Eta kare $\left(\eta^{2}\right)$ ise .115 olarak tespit edilmiştir ve bu değer orta ile büyük arasındadır. $\eta^{2}$ değerleri .01, .06, .14 olarak sırasıyla küçük, orta, ve büyük etki değeri olarak kabul edilmektedir (Green, Salkind, ve Akey, 2000, s. 159). Ek olarak, cinsiyetin ana etkisi istatistiksel olarak anlamlı bulunmamıştır: $F(1,59)=.045, p=.833$. Etki büyüklüğü de bu sonucu destekler niteliktedir: $\eta^{2}=.001$. Green vd. (2000) kriterlerine göre bu eta kare değerinin oldukça küçük olduğu görülmektedir. Bu sonuç, kızlar ve erkeklerin uygulanan her iki yöntemden eşit seviyede fayda sağladıklarına işaret etmektedir.

Son olarak, deney ve kontrol grubunun öntest ve sontest puanları üzerinden yaratılan Kazanç Puanı arasında istatistiksel olarak anlamlı bir fark olup olmadığını (Araştırma Problemi 5 ) incelemek üzere yapılan ilişkili örneklemler t-testi sonuçları Tablo 12'de verilmiştir.

Tablo 12

Deney ve Kontrol Grubuna Ait Kazanç Puanı (Sontest-Öntest) İlişkili Örneklemler T-Testi Sonuçları

\begin{tabular}{cccccc}
\hline Grup & $\mathrm{N}$ & $\overline{\mathrm{X}}$ & $\mathrm{sd}$ & $\mathrm{t}$ & $\mathrm{p}$ \\
\hline Deney & 32 & 23.66 & 13.20 & -3.354 & .001 \\
Kontrol & 32 & 12.19 & 14.14 & & \\
\hline
\end{tabular}

Deney grubunun kazanç puan ortalaması $23.66\left(\mathrm{SD}_{\text {kazanç }}=13.20\right)$ iken kontrol grubunun kazanç puan ortalaması $12.19\left(\mathrm{SD}_{\text {kazanç }}=14.14\right)$ 'dur. Tablo 12'de görüldüğü gibi uygulanan yöntem kazanç puanları üzerinde de istatistiksel olarak anlamlı bir fark yaratmıştır $(\mathrm{p}<.05)$. Bu sonuç, deney grubu öğrencilerinin veri analizi konusundaki bilgilerini portfolyo kullanımı ile değerlendirildiklerinde geliştirebildiklerini ve bu yöntemin onların istatistik başarısına olumlu katkı sağladığına işaret etmektedir.

\section{Tartışma, Sonuç ve Öneriler}

Çalışmanın sonuçları, portfolyo değerlendirmesi kullanılan sürecin mevcut öğretime göre 7. sınıf öğrencilerinin genel olarak istatistik, özel olarak veri analizi konusundaki başarılarına istatistiksel olarak anlamlı bir etkisinin olduğunu göstermiştir. Yöntemsel açıdan, bulgular kontrol grubunda yer alan öğrencilerin öntest ve sontest İBT puanları arasında anlamlı bir fark olmadı̆̆ını gösterirken, deney grubunda yer alan öğrencilerin İBT öntest ve sontest puanları arasında anlamlı bir fark olduğuna işaret etmektedir. Kontrol grubunda anlamlı bir fark elde edilememesi, veri analizi ünitesinin ders kitabından takip edilmesi, soru-cevap şeklinde yürütülmesi ve öğrencilerin 
klasik oturma düzeninde dersi izlemesi ile açıklanabilir. Deney grubunda ise öğrenciler veri analizi konusunda haftalık görevleri tamamlayarak kendi çalışmalarını amaçlı bir şekilde toplamışlar ve bu çalışmalarını yansıtıcı ve işbirliği içinde yapılandırarak toplamışlardır. $\mathrm{Bu}$ doğrultuda bulgular da göz önüne alınarak deney grubundaki öğrencilerin uygulama sürecinden yeterli seviyede fayda sağladıkları söylenebilir.

Çalışmanın sonuçları İstanbul ili Fatih ilçesi devlet ortaokullarında eğitim-öğretim gören öğrencilere genellenebilir. Ancak uygulanan portfolyo değerlendirmesinin yaratmış olduğu etki büyüklüğünün gelecek araştırmacılar tarafından dikkate alınması gerekir. Çalışmanın sonuçlarına bakılarak öğrencilerin tüm matematik dersi konularında portfolyo hazırlama yöntemine dayandırılarak değerlendirilmesi şeklinde kesin bir vurgu yapılamaz. Fakat genel olarak istatistik eğitiminin, özel olarak ise veri analizi konusunun portfolyo değerlendirmesinin entegre edildiği ders planları, etkinlik, ve haftalık görevlerle zenginleştirildiğinde öğrencilerin başarısına olumlu katkı sağlayacağı ve onların başarısında istatistiksel olarak anlamlı bir etki yaratacağ söylenebilir.

Araştırmadan elde edilen bulgular daha önce portfolyo değerlendirmesinin istatistik başarısı üzerine etkisini inceleyen bir çalışmanın olmamasından dolayı önceki araştırmaların sonuçları ile karşılaştırılamamıştır. Ancak, çalışmanın sonuçları portfolyo değerlendirmesinin genel olarak akademik başarı (ör., AlKhateeb, 2018; Başol ve Erbay, 2017; Taşdemir, Taşdemir, ve Yıldırım, 2009; Turan ve Sakız, 2014) ve özel olarak matematik başarısı (ör., Abalı-Öztürk ve Şahin, 2014; Aktay ve Gültekin, 2014; Crowley, 1993) üzerine istatistiksel olarak anlamlı bir etkisi olduğunun altını çizen geçmiş araştırmaları destekleyen niteliktedir. Elde edilen sonuçlar, portfolyo değerlendirmesinin öğrencilerin matematiğe karşı tutumlarını olumlu yönde etkilediğini gösteren çalışmaların (ör., Belecina, 2008; Demirel, 2015; Gencel, 2017; Karakuş ve Bolat, 2014) sonuçlarıyla da paralellik göstermektedir. Ayrıca öğrencilerin matematiksel tutumlarının yordanmasında öğretmen tarafından verilen performans görevi ile ilgili araştırma becerisinin önemli bir değişken olduğu fark edilmiştir (Karakuş ve Bolat, 2014).

İstatistik eğitimine odaklanan çalışmalar oldukça sınırlı olmakla birlikte, literatürde uygulanan farklı öğretim yöntemlerinin (ör., bilgisayar destekli eğitim) öğrencilerin istatistik başarısına ve istatistiğe karşı tutumlarına olumlu katkı sağladığını vurgulayan araştırmalar da mevcuttur (Doğan, 2009; Schuyten ve Dekeyser, 2007; Petrocelli, 2007; Y1lmaz ve Sonay-Ay, 2016). Pfannkuch (2018) gazete makaleleri, medya raporları, vb. kullanımının öğrencilerin istatistik başarısını ve istatistiğe karşı tutumlarını olumlu yönde etkilediğini belirtmiştir. $\mathrm{Bu}$ bağlamda, farklı bir ölçme-değerlendirme yöntemi olarak portfolyo değerlendirmesi hazırlanması aşamasında içerdiği benzer materyaller bakımından istatistik başarısına etki etme potansiyeline sahiptir ve bu çalışmanın sonuçlarından da görüldüğü üzere istatistik başarısına olumlu katkı sağlamıştır.

Sonuç olarak, tüm bulgular kazanç puanları (bknz. Tablo 12) ile birlikte değerlendirildiğinde, bu araştırmada portfolyo değerlendirmesinin istatistik başarısını deney grubu lehine artırdığı tespit edilmiştir. Elde edilen sonuçlardan ve edinilen deneyimlerden hareketle matematik eğitimine olumlu katkı sağlaması ve özel olarak istatistik eğitimi alanında inceleme yapacak olan araştırmacılara 1şık tutması amacıyla geliştirilen öneriler aşağıdaki satırlarda yer almaktadır.

Portfolyo uygulaması hazırlama ve değerlendirme süreci bakımından diğer yöntemlere göre daha uzun süre/fazla zaman gerektirdiğinden ders planları çok iyi hazırlanmalıdır. Portfolyo değerlendirmesi farklı sinıf düzeylerinde (ör., lise), farklı ünitelerde (ör., fonksiyonlar), farklı bilişsel (ör., matematiksel düşünme) ve duyuşsal (ör.,başarı duygusu) değişkenler ele alınarak uygulanabilir. Literatürdeki ögretmenlerin portfolyo değerlendirmesine yönelik görüşlerine yer veren çalışmaların (ör., Orbeyi ve Güven, 2008) işaret ettiği üzere öğretmenler portfolyo değerlendirmesini sıklıkla kullandıklarını fakat bu yöntemi çok vakit alıcı bulduklarını ve puanlama esnasında zorluk yaşadıklarını belirtmişlerdir.Dolayısıyla, araştırma sonuçları göz önünde tutularak portfolyo değerlendirme sürecinde zaman etkili kullanılmalıdır. Bu çalışmanın güçlü yanlarından birisi de ortaokul matematik eğitiminde uzun yıllar deneyime sahip matematik öğretmeni ile iş birliği içerisinde çalışılmasıdır. Portfolyonun her ne kadar öğretmenler için 
öğretim sürecinde zaman alan bir uygulama olduğu ve zorluk çektikleri belirtilsede (örn., Önel ve diğerleri, 2020),bu çalışma araştırmacıların portfolyo içeriğini hazırlama, uygulama ve öğrencilere geri bildirim verme sürecinde öğretmeni birebir desteklemesinin araştırmayı olumlu yönde ilerlettiğini göstermiştir. Uzun yıllar deneyime sahip (örn. 15 y1lın üzerinde) öğretmenler ile çalışmanın avantajlarından birisi de öğretmenin uygulamadaki programa, kazanımlara, içeriğe ve özellikle de sınıfındaki öğrencinin ne bilip bilmediğine hâkim olmasıdır. Ancak şu da eklenmelidir ki öğrencilerin test puanları arasındaki fark kontrol grubunda kullanılan soru cevap yönteminin deney grubunda kullanılan portfolyo hazırlamaya göre daha düşük bilişsel düzeyde olmasıyla da ilgili olabilir. Sonuçlarımızın bu bağlamda sınırlı olduğunu söyleyebiliriz. İleriki çalışmalarda gerçek deneysel araştırma desenlerinin kullanılmasının (örn. Solomon dört grup modeli gibi) (Zorlu ve Zorlu, 2019) portfolyonun etkisinin daha iyi araştırılması açısından önemli olduğu düşünülmektedir.

Hiç şüphesiz, öğretim programlarındaki değişim, öğretmenlerin öğretmenlik tecrübelerini geçmiş ve güncel deneyimleri ile yeniden yapılandırmalarını gerektiren zorlu bir süreçtir (Özcan, Oran ve Arık, 2018). Bu bağlamda, öğretmenlere alternatif ölçme-değerlendirme yöntemlerinden biri olan portfolyo hazırlama temel bilgi ve becerileri kapsamında hizmet-içi eğitimler verilebilir.

\section{Teşekkür}

$\mathrm{Bu}$ araştırmanın tasarımında danışmanlığını esirgemeyen Boğaziçi Üniversitesi Eğitim Fakültesi İlköğretim Matematik Öğretmenliği Bölümü’nün değerli akademisyenlerine teşekkür ederiz. Zorlu pandemi sürecinde çalışmamıza önemli katkı sağlayan yapıcı eleştirilerinden dolayı anonim hakemlere, değerli görüşleri için dergi bölüm editörüne, teknik desteği için dergi editörüne ve bilhassa soru hazırlama aşamasında uzman görüşünü ve yılların deneyimini bizimle paylaşan değerli matematik öğretmeni Cemile Birgili’ye sonsuz teşekkürlerimizle.

\section{Araştırma ve Yayın Etiği}

04.08.2020 ODTÜ İnsan Araştırmaları Etik Kurulu Kararı, sayı: 28620816/218

\section{Kaynaklar}

Abal1-Öztürk, Y. ve Şahin, Ç. (2014).Alternatif ölçme değerlendirme yöntemlerinin akademik başarı, kalıcılık, özyeterlilik algısı ve tutum üzerine etkisi. Eğitimde Kuram ve Uygulama, 10(4), 1022-1046.

Aktay, S. ve Gültekin, M. (2014). İlköğretimde webfolyo uygulaması: Öğretmen ve öğrenci görüşleri. İlkögretim Online, 13(3), 806-819.

AlKhateeb, M. A. (2018).The effect of using performance-based assessment strategies to tenthgrade students' achievement and self-efficacy in Jordan. Cypriot Journal of Educational Science, 13(4), 489-500.

Amerikan Matematik Öğretmenleri Birliği (National Council of Teachers of Mathematics) [NCTM] (2000). Executive Summary: Principles and Standards for School Mathematics. Association Drive Reston, VA. Erişim adresi: https://www.nctm.org /uploaded Files/ Standards_and_Positions/PSSM_ExecutiveSummary.pdf.

Başol, G. ve Erbay, Ş. (2017). Portfolyo kullanımının akademik başarıya etkisi: Bir meta analiz çalışması. Hacettepe Üniversitesi Ĕ̈itim Fakültesi Dergisi, 32(2), 396-412.

Belecina, R. R. (2008). Portfolio as an alternative assessment: Effects on problem-solving performance, critical thinking, and attitude in mathematics. The Nominal Rights, 3(1), 5481.

Ben-Hur, M. (2006).Concept-rich mathematics instruction.Association for supervision and curriculum development, Alexandria, Virginia, USA.

Ben-Zvi, D., Gravemeijer, K. ve Ainley, J. (2018). Design of statistics learning environments. D. Ben-Zvi, K. Makar ve J. Garfield (Yay. haz.) International Handbook of Research in Statistics Education. Springer International Handbooks of Education.Springer, Cham. 
Biehler, R., Frischemeier, D., Reading, C. ve Shaughnessy, M. J. (2018). Reasoning about data. D. Ben-Zvi, K. Makar ve J. Gargield (Yay. haz.). International Handbook of Research in Statistics Education. Switzerland: Springer.

Birgin, O. ve Baki, A. (2007). The use of portfolio to assess student's performance. Journal of Turkish Science Education, 4(2), 75-90.

Bloom, B. S. Engelhart, M. D., Furst, E. J., Hill, W. H., Krathwohl, D. R. (1956). Taxonomy of educational objectives: The classification of educational goals. Handbook 1: Cognitive domain. New York: David McKay.

Burks, R. (2010). The student mathematics portfolio: Value added to student preparation? Primus: Problems, Resources and Issues in Mathematics Undergraduate Studies, 20(5), 453-473.

Büyüköztürk, Ş. (2012). Veri analizi el kitabı.(17. Bask1). Ankara: Pegem Akademi.

Chance, B. L. (2002). Components of statistical thinking and implications for instruction and assesment. Journal of Statistics Education. Erişim adresi: http://www.amstat.org/ publications/jse/v10n3/chance.html.

Crowley, M. L. (1993). Student mathematics portfolio: More than a display case. The Mathematics Teacher, 86(7), 544-547.

Çakmak, Z., Çetin, Ö. F. ve Bektemir, M. (2016).Sekizinci sınıf öğrencilerinin istatistik konusundaki matematiksel dil becerilerinin yapısal eşitlik modeli ile incelenmesi. Illköğretim Online, 15(2), 299-317.

Demirören, M., Koşan, A. M. ve Palaoğlu, Ö. (2009). Bir öğrenme ve değerlendirme yöntemi olarak "portfolyo". Ankara Üniversitesi Tip Fakültesi Mecmuası, 62(1), 19-24.

Doğan, N. (2009).Bilgisayar destekli istatistik öğretiminin başarıya ve istatistiğe karşı tutuma etkisi. Eğitim ve Bilim, 34(154), 3-16.

Fraenkel, J., Wallen, N. ve Hyun, H. (2014). How to design and evaluate research in education ( $9^{\text {th }}$ ed.). NY: McGraw-Hill Education.

Gal, I. (2002). Adult statistical literacy: Meanings, components, responsibilities. International Statistical Review, 70(1), 1-25.

Garfield, J. ve Ahlgren, A. (1988). Difficulties in learning basic concepts in probability and statistics: implications for research. Journal for Research in Mathematics Education, 19(1), 44-63.

Garfield, J. ve Gal, I. (1999). Assessment and statistics education: Current challenges and directions. International Statistical Review, 67(1), 1-12.

Gay, L. R. ve Airasian, P. (2000). Educational research: Competencies for analysis and application. Upper Saddle River, NJ: Merrill.

Gelbal, S. ve Kelecioğlu, H. (2007).Öğretmenlerin ölçme değerlendirme yöntemleri hakkındaki yeterlik algıları ve karşılaştıkları sorunlar. Hacettepe Üniversitesi Eğitim Fakültesi Dergisi, 33, 135-145.

Gencel, İ. E. (2017). The effect of portfolio assessments on metacognitive skills and on attitudes toward a course. Kuram ve Uygulamada Eğitim Bilimleri, 17(1), 293-319.

Ghoorchaei, B., Tavakoli, M. ve Ansari, D. N. (2010). The impact of portfolio assessment on Iranian efl students' essay writing: a process-oriented approach. GEMA Online Journal of Language Studies, 10(3), 35-51.

Gil, E. ve Ben-Zvi, D. (2014). Long term impact of the connections program on students' informal inferential reasoning. K. Makar, B. de Sousa ve R. Gould (Yay. haz.). Sustainability in statistics education (Proceedings of the Ninth International Conference on Teaching Statistics, ICOTS9, July 2014). Voorburg, The Netherlands: International Association for Statistical Education and International Statistical Institute.

Green, S. B., Salkind, N. J. ve Akey, T. M. (2000). Using SPSS for windows analyzing and understanding data (2nd ed.). Upper Saddle River Prentice-Hall.

Güneş, G. ve Baki, A. (2011). Dördüncü sınıf matematik dersi öğretim programının uygulanmasından yansımalar. Hacettepe Üniversitesi Ĕgitim Fakültesi Dergisi, 41, 192205. 
Hargreaves, D. J. (1997). Student learning and assessment are inextricably linked. European Journal of Engineering Education, 22(4), 401-409.

Henderson, J. L., Davis, R. R. ve Day, T. M. (1995). Developing portfolios to document student performance and accomplishments. North American Colleges and Teachers of Agriculture (NACTA), 39(4), 18-21.

IKSV Tasarım (Şubat, 2007). İKSV Tasarım'dan çok özel yapıt-kitap: 'Rengâhenk'. Erişim adresi: http://www.radikal.com.tr/kultur/iksv-tasarimdan-cok-ozel-yapit-kitap-renghenk805190/

Jones, G. A., Langrall, C. W., Mooney, E. S. ve Thornton, C. A. (2004). Models of development in statistical reasoning. J. Garfield ve D. Ben-Zvi (Yay. haz.). The Challenge of Developing Statistical Literacy, Reasoning and Thinking içinde (ss. 201-226). Dordrecht, The Netherlands: Kluwer.

Jones, G. A., Thornton C. A., Langrall, C. W., Mooney, E. S., Perry, B. ve Putt, I. J. (2000), A framework for characterizing children's statistical thinking. Mathematical Thinking and Learning, 2(4), 269-307.

Kan, A. (2007). Portfolyo değerlendirme. Hacettepe Üniversitesi Eğitim Fakültesi Dergisi, 32, 133-144.

Karakuş, M. ve Bolat, Y. (2014).İlköğretim beşinci sınıf öğrencilerinin performans görevlerine yönelik tutumlarını yordayan değişkenlerin belirlenmesi. Mersin Üniversitesi Eğitim Fakültesi Dergisi, 10(3), 22-30.

Karaman, P. ve Şahin, Ç. (2013). Öğretmen adaylarının ölçme değerlendirme okur-yazarlıklarının belirlenmesi. Ahi Evran Üniversitesi Kırşehir Eğitim Fakültesi Dergisi (KEFAD), 15(2), 175-189.

Kılıç, Ç. (2012). İlköğretim matematik dersi (1-5 sınıflar) öğretim programında yer alan problem kurma çalışmalarının incelenmesi. Mersin Üniversitesi Eğitim Fakültesi Dergisi, 7(2), 54-65.

Kınay, İ. (2015).Otantik değerlendirme yaklaşımının ögretmen adaylarının problem çözme becerileri ile öğrenmeye ve katılımcı değerlendirmeye yönelik inançlarına etkisinin incelenmesi (Yayınlanmamış doktora tezi). Gaziantep Üniversitesi, Eğitim Bilimleri Enstitüsü, Gaziantep.

Koca, S. A. ve Lee, H. J. (2001). Portfolio assessment in mathematics education, 4-7. (Eric No. ED 434802).

Koparan, T. (2013). İstatistiksel düşünme modellerinin incelenmesi. İlköğretim Online, 12(3), 730-739.

Koparan, T. ve Güven, B. (2014a).Ortaokul öğrencilerinin istatistiksel düşünme seviyelerinin m3st modeline göre incelenmesi. Eğitim ve Bilim, 39(171), 37-51.

Koparan, T. ve Güven, B. (2014b). 8. sınıf öğrencilerinin örneklem kavramına yönelik istatistiksel okuryazarlık seviyelerinin belirlenmesi. Illkögretim Online, 13(4), 1171-1184.

Krippendorff, K. (2004). Content analysis: An introduction to its methodology. Thousand Oaks, California: Sage.

Krippendorff, K. (2011). Computing Krippendorff's alpha-reliability. Philadelphia: Annenberg School for Communication Departmental Papers. Erişim adresi: http://repository.upenn.edu/cgi/viewcontent.cgi?article=1043\&context=asc_papers.

Lombardi, J. (2008). To Portfolio or not to Portfolio: Helpful or Hyped? College Teaching, 56(1), $7-10$.

Lustig, K. (1996). Portfolio assessment. A Handbook for Middle Level Teachers. National Middle School Association, Columbus, $\mathrm{OH}$.

Makar, K. ve Rubin, A. (2017). Research on inference. D. Ben-Zvi., K. Makar ve J. Garfield (Yay. haz.). International Handbook of Research in Statistics Education. Switzerland: Springer.

Makar, K. ve Rubin, A. (2018). Learning about statistical inference. D. Ben-Zvi, K. Makar ve J. Gargield (Yay. haz.). International handbook of research in statistics education. Switzerland: Springer. 
Mamur, N. (2012). Görsel sanatlar eğitiminde nitel araştırmalar için bir doküman: Portfolyo. Eğitim ve Bilim, 37(165), 194-207.

McMillan, J. M. (2007). Classroom assessment: Principles and practices for effective standard based instruction (4th ed.). Boston, MA: Pearson.

MEB (2005). Illkögrretim Matematik Dersi (1-5) Öğretim Programı. Ankara: Devlet Kitapları Müdürlüğü. Basım Evi.

MEB (2018). Matematik Dersi Öğretim Programı (Illkokul ve Ortaokul 1,2,3,4,5,6,7 ve 8. Sinıflar). Ankara: Milli Eğitim Bakanlığı.

Mutlu, N. ve Özden, M. Y. (2017). Fen ve teknoloji öğretmenlerinin alternatif ölçme ve değerlendirme yöntemlerine yönelik ihtiyaç analizi. Mersin Üniversitesi Ĕgitim Fakültesi Dergisi, 13(3), 936-948.

Nezakatgoo, B. (2011). The Effects of Portfolio Assessment on Writing of EFL Students. Canadian Center of Science and Education: English Language Teaching, 4(2), 231-241.

Nunnally, J. C. (1967). Psychometric theory. New York: McGraw-Hill.

Okçu, Y. (2007). Matematik e ğitiminde portfolyo değerlendirme (Yayımlanmamış yüksek lisans tezi). Ortaöğretim Fen ve Matematik Alanları Eğitimi, Balıkesir Üniversitesi, Balıkesir.

O’Neil, H. F. ve Schacter, J. (1997). Test specifications for problem-solving assessment. [CSE Technical Report 463]. National Center for Research on Evaluation, Standards, and Student Testing, Los Angeles, CA.

Onwuegbuzie, A. J. ve Leech, N. L. (2003). Assessment in statistics courses: More than a tool for evaluation. Assessment \& Evaluation in Higher Education, 28(2), 115-127.

Orbeyi, S. ve Güven, B. (2008).Yeni ilkögretim matematik dersi ögretim programı'nın değerlendirme öğesine ilişkin öğretmen görüşleri. Eğitimde Kuram ve Uygulama, 4(1), 133-147.

Önel, F., Dalkılınç, F., Özel, N., Deniz, Ş., Balkaya, T. ve Kurt Birel, G. (2020). Ortaokul matematik öğretmenleri ölçme-değerlendirmeyi nasıl yapıyor? Bir durum çalışması. Kastamonu Education Journal, 28(3), 1448-1459.

Özcan, H., Oran, Ş. ve Arık, S. (2018). Fen Bilimleri dersi 2013 ve 2017 öğretim programlarının öğretmen görüşlerine göre karşılaştırmalı incelenmesi. Başkent University Journal of Education, 5(2), 156-166.

Özdemir. O. ve Erdemci, H. (2017). The effect of mobile portfolio (m-portfolio) supported mastery learning model on students' achievement and their attitudes towards using internet. Journal of Education and Training Studies, 5(3), 62-70.

Petocz, P., Reid, A. ve Gal, I. (2018). Statistics education research. D. Ben-Zvi, K. Makar ve J. Gargield (Yay. haz.). International Handbook of Research in Statistics Education. Switzerland: Springer.

Petrocelli, J. V. (2007). The utility of computer-assisted power analysis lab instruction. Teaching of Psychology, 34(4), 248-252.

Pfannkuch, M. (2018). Reimagining curriculum approaches. D. Ben-Zvi, K. Makar ve J. Gargield (Yay. haz.). International Handbook of Research in Statistics Education. Switzerland: Springer.

Polat-Demir, B. ve Kutlu, Ö. (2016).The effect of electronic portfolyo applications on 6th graders' research skills. Education and Science, 41(188), 227- 253.

Popham, W. J. (2011). Classroom assessment: What teachers need to know. Boston, MA: Pearson.

Rudner, L. M. ve Schafer, W. D. (2002). What teachers need to know about assessment. Washington, DC: National Education Association. Erişim adresi: http://echo.edres.org:8080/nea/teachers.pdf

Schield, M. (2004). Statistical literacy curriculum design. IASE Roundtable, Lund, Sweden.

Sharp, J. (2002). Using portfolios in the classroom. Proceedings of the Frontiers in Education Conference, USA, içinde (ss. 272-279). Erişim adresi: http://citeseerx.ist.psu.edu/viewdoc/download?doi=10.1.1.197.5200\&rep=rep1\&type=df 
Schindler, M. ve Seidouvy, A. (2019). Informal inferential reasoning and the social: Understanding students' informal inferences through an inferentialist epistemology. G. Burrill ve D. Ben-Zvi (Yay. haz.). Topics and Trends in Current Statistics Education Research içinde (ss. 153-171). Cham: Springer.

Sireci, S. ve Faulkner-Bond, M. (2014). Validity evidence based on test content. Psicothema, 26(1), 100-107.

SPSS (2012). IBM SPSS Statistics for Windows, Version 21. Boston, Mass: International Business Machines Corporation.

Struyyen, K., Dochy, F., Janssens, S., Schelfout, W. ve Gielen, S. (2006). The overall effects of end-of-course assessment on student performance: a comparison between multiple choice testing, peer assessment, case-based assessment and portfolio assessment. Studies in Educational Evaluation, 32(1), 202-222.

Temiz, B. K. ve Tan, M. (2009). Lise 1. sinıf öğrencilerinin grafik yorumlama becerileri. Selçuk Üniversitesi Ahmet Keleşoğlu Eğitim Fakültesi Dergisi, 28(1), 31-43.

Tishkovskaya, S. ve Lancaster, G. A. (2010). Teaching strategies to promote statistical literacy: Review and implementation. International Association of Statistical Education. United Kingdom: Lancaster University.

Tiwari, A. ve Tang, C. (2003). From process to outcome: The effect of portfolio assessment on student learning. Nurse Education Today, 23(1), 269-277.

Toptaş, V. (2011).Sınıf öğretmenlerinin matematik dersinde alternatif ölçme ve değerlendirme yöntemlerinin kullanımı ile ilgili algıları. Eğitim ve Bilim, 36(159), 205-219.

Turan, M. A. ve Sakız, G. (2014). Fen ve teknoloji dersinde portfolyo kullanımının öğrenci bașarısı ve kalıcılığa etkisi. Mersin Üniversitesi Eğitim Fakültesi Dergisi, 10(3), 48-63.

Verhoeven, P. (2006). Statistics education in the Netherlands and Flanders: An outline of introductory courses at universities and colleges. In ICOTS-7 Conference Proceedings.

Watson, J., Fitzallen, N., Fielding-Wells, J. ve Madden, S. (2018). The practice of statistics. D. Ben-Zvi, K. Makar ve J. Gargield (Yay. haz.). International handbook of research in statistics education. Switzerland: Springer.

Yanpar-Yelken, T. (2009). Öğretmen adaylarının portfolyoları üzerinde grup olarak yaratıcılık temelli materyal geliştirmenin etkileri. Eğitim ve Bilim, 34(153), 83-98.

Yılmaz, N. ve Sonay-Ay, Z. (2016).Sekizinci sınıf öğrencilerinin histograma dair bilgi ve becerilerinin incelenmesi. Illkögretim Online, 15(4), 1280-1298.

Zieffler, A., Garfield, J. ve Fry, E. (2018). What is statistics education? D. Ben-Zvi, K., Makar ve J. Garfield (Yay. haz.). International Handbook of Research in Statistics Education içinde (ss. 37-70). Cham, Switzerland: Springer.

Zorlu, F. ve Zorlu, Y. (2019). Eğitim alanında solomon deneysel deseni ile gerçekleştirilen çalışmaların incelenmesi: Bir tematik analiz çalışması. Kastamonu Eğitim Dergisi, 27(4), $1623-1636$.

\section{Etik Kurul Onay Bilgileri}

Bu araştırma, Orta Doğu Teknik Üniversitesi (ODTÜ) İnsan Araştırmaları Etik Kurulu (İAEK) tarafından incelenmiş, 28620816/218 sayılı karar ile uygun görülmüş ve 2018 ODTU 2020 protokol numarası ile 04 Ağustos 2020 tarihinde onaylanmıştır.

\section{Extended Abstract}

\section{Introduction}

Assessment is integral to teaching and learning mathematics, and it plays an important role in how and what teachers teach, as well as in how and what students learn. Curriculum documents (MoNE, 2018; NCTM, 2000) posit to the advantages of using constructivist assessment methods that prompts student learning as "process".

In this accordance, portfolio is one of the alternative assessment techniques that allows teachers to collect information about students' understanding of mathematics and to build links 
between their mathematical strengths and weaknesses. From an educational measurement and evaluation perspective, traditional paper-pencil tests used to measure mathematics achievement fail to assess students' problem-solving and creative thinking skills. In contrast, portfolios provide teachers with the opportunity to display student' higher-order thinking skills in a more flexible manner. By doing so, teachers are further able to focus on how to develop those skills.

Although portfolio assessment became widely used from early years of primary education to higher education in recent years, it has also some disadvantages: (1) the reliability of scoring is low, (2) guiding students needs time, and (3) the preparation requires detailed investigation. However, studies that focus on teachers' conceptions about the use of portfolios indicated that the majority of teachers have positive attitudes towards using portfolios and that they perceive portfolio as an effective assessment tool. Indeed, researchers underlined the significant effect of portfolio assessment on student performance (see Başol \& Erbay, 2017 metaanalysis for detailed review).

Statistics education is a multidisciplinary area that emerged from mathematics education. Data Analysis and Probability is one the most important topics in statistics education as it plays a crucial role in decision making with regard to the data collection and the interpretation of results. Research in statistics education focused on statistics achievement and attitudes towards statistics (Doğan, 2009), statistical thinking (Koparan \& Güven, 2014a), statistics literacy (Karaman \& Şahin, 2013), statistical language skills (Çakmak, Çetin \& Bektemir, 2016) and statistical thinking models (Chance, 2002). The vast majority of research involved middle school students, and to a lesser extent, elementary, secondary, and university students. From a methodological perspective, most of the studies were quantitative and used experimental, longitudinal, and structural equation modeling techniques. In common, national and international studies underlined most of the students encounter difficulties in understanding fundamental statistics concepts and procedures.

The purpose the present study is to explore the effect of portfolio assessment on statistics achievement. Henceforth, the overarching research question is the following: Is there a statistically significant effect of portfolio assessment on 7th grade students' statistics achievement?

\section{Method}

In the present study quasi-experimental design was used. The research was carried out with 7th grade students in two different classes, who are attending to a public school in Fatih, İstanbulTurkey. A total of 64 students $(n=32$ in experimental and $n=32$ in control) participated in this quasi-experimental study. Students' statistics achievement was measured through the researcherdeveloped Statistics Achievement Test (SAT), which covered data analysis unit.

The quantitative data was obtained from the results of pre-test and post-test measurement within the 6-week treatment. The difference between the post-test scores was investigated by controlling pre-test scores and gender. In the experimental group the data analysis unit was carried out in guidance of the current middle school mathematics program plus the portfolio preparation techniques, whereas in the control group only the activities and examples present in the current middle school mathematics program was used. Data were analyzed by performing Paired Samples t-Test, Independent Samples t-Test, and Two-Factor ANCOVA.

\section{Result and Discussion}

Findings of the present study indicated that portfolio assessment, as compared to traditional assessment techniques, had a significant effect on 7th grade students' statistics achievement in general, and data analysis unit, in particular.

More specifically, results revealed that there was no statistically significant mean difference between the pretest scores of the students who received portfolio assessment and those who were exposed to traditional instruction $(\mathrm{t}(62)=1.69, p>.05)$. There was a statistically significant mean difference between the posttest scores of the students who received portfolio assessment and those who were exposed to traditional instruction, while controlling fort he gender and prestest scores $(F(1,59)=7.669, p=.007)$. 
Birgili ve Aydın

The findings support previous research indicating that portfolio assessment had a significant impact on academic achievement (AlKhateeb, 2018; Başol \& Erbay, 2017; Taşdemir, Taşdemir \& Yıldırım, 2009) in general and on mathematics achievement (Abalı-Öztürk \& Şahin, 2014; Crowley, 1993) in particular. From an instructional point of view, a longitudinal study is warranted for a better understanding of the development of students' higher-order thinking skills throughout the process of learning data analysis. 